University of Massachusetts Amherst

ScholarWorks@UMass Amherst

Doctoral Dissertations 1896 - February 2014

$1-1-1981$

\title{
Effects of estradiol and progesterone on food intake, body weight, and carcass adiposity in weanling rats.
}

Susan M. Schwartz

University of Massachusetts Amherst

Follow this and additional works at: https://scholarworks.umass.edu/dissertations_1

\section{Recommended Citation}

Schwartz, Susan M., "Effects of estradiol and progesterone on food intake, body weight, and carcass adiposity in weanling rats." (1981). Doctoral Dissertations 1896 - February 2014. 1556.

https://doi.org/10.7275/0dmp-3972 https://scholarworks.umass.edu/dissertations_1/1556

This Open Access Dissertation is brought to you for free and open access by ScholarWorks@UMass Amherst. It has been accepted for inclusion in Doctoral Dissertations 1896 - February 2014 by an authorized administrator of ScholarWorks@UMass Amherst. For more information, please contact scholarworks@library.umass.edu. 
EFFECTS OF ESTRADIOL AND PROGESTERONE ON

FOOD INTAKE, BODY WEIGHT, AND CARCASS ADIPOSITY IN WEANLING RATS

A Dissertation Presented

By

SUSAN M. SCHWARTZ

Submitted to the Graduate School of the University of Massachusetts in partial fulfillment of the requirements for the degree of

DOCTOR OF PHILOSOPHY

September $\quad 1981$

Department of Psychology 


\section{EFFECTS OF ESTRADIOL AND PROGESTERONE ON FOOD INTAKE, BODY WEIGHT, AND \\ CARCASS ADIPOSITY IN WEANLING RATS}

\section{A Dissertation Presented}

By

SUSAN M. SCHWARTZ

Approved as to style and content by:
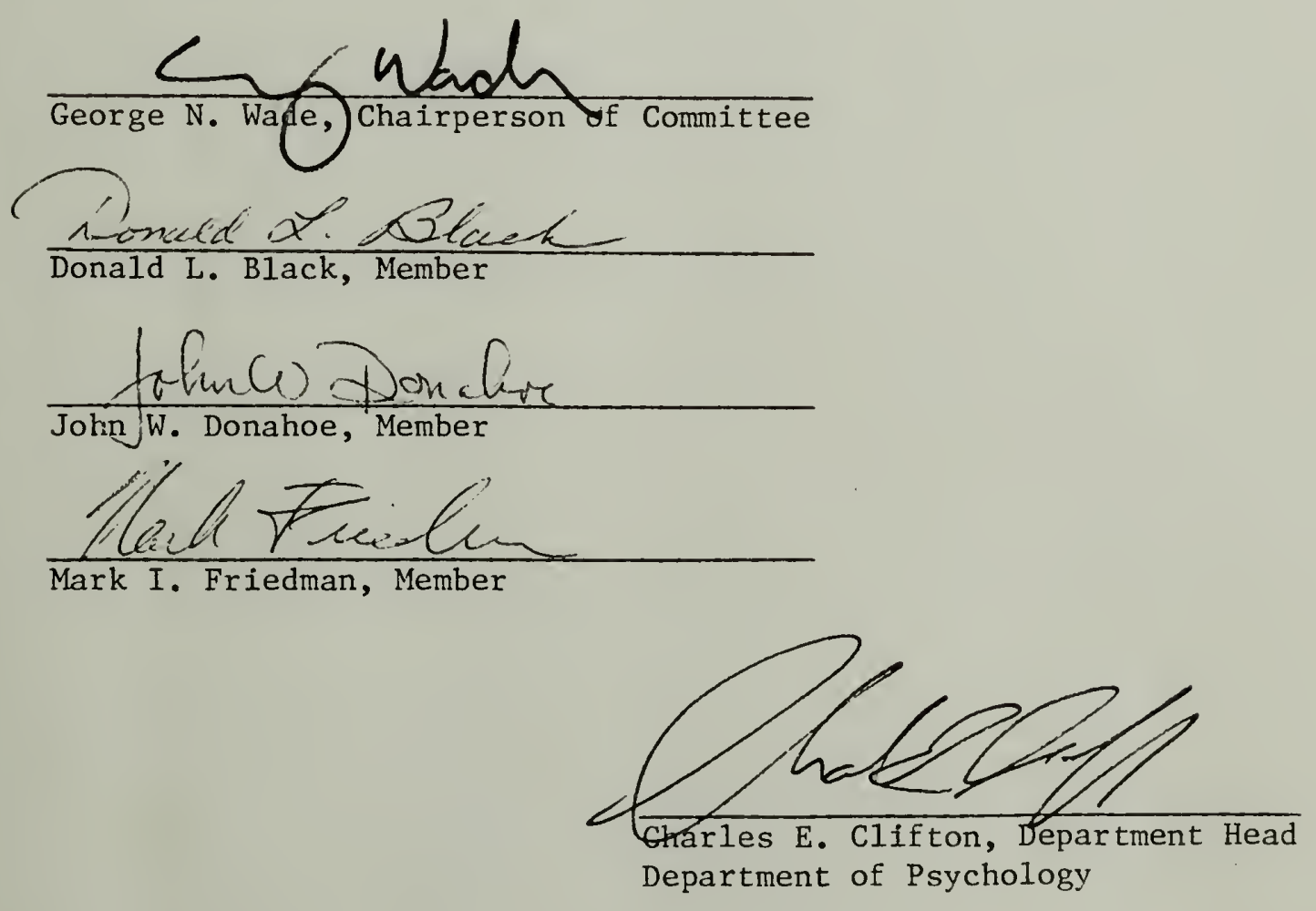


\section{ACKNOWLEDGEMENTS}

This dissertation could not have been accomplished without the help and encouragement of certain individuals. I would like to extend my sincere thanks:

To George Wade, for his support, encouragement, assistance and his patience in helping me find my niche.

To Mark Friedman, John Donahoe and Donald Black, for serving as committee members and providing me with helpful comments for the final manuscript.

To Tony Nunez, for his support and for his sharing with me his insights both in and out of the academic world.

To Lindi Siege1, for being a wonderful colleague and friend during the past four years and for always knowing "what I was trying to say".

To Janet Gray, for being a great and patient teacher and a most tolerant office mate.

To Joy Littlejohn for her technical assistance and her constant assurances to "stay calm".

To Christina Decoteau, for the typing of this final draft and for knowing a11 the rules.

To all my friends and colleagues in the lab who have been very supportive during the writing of this dissertation.

To Karen Gil, for sharing with me ideas, feelings and her wonderful view of the world. 
To Ken Stickney, for his companionship, encouragement and incredible patience.

To my parents, for instilling in me the belief to "go for it".

This dissertation was supported by National Institute of Neurological and Communicative Disorders and Stroke Research Grant NS10873 and Research Career Development Award NS-00090, by National Institute of Arthritis, Metabolism, and Digestive Diseases Research Grant AM-20785, and by National Institute of Mental Health Research Scientist Development Award MH-00321 and Training Grant MH-11823. 


\title{
ABSTRACT
}

Effects of Estradiol and Progesterone on Food Intake, Body Weight, and Carcass Adiposity in Weanling Rats (September, 1981)

\author{
Susan M. Schwartz, B.S., Simmons College \\ M.S., Buckne11 University, Ph.D., University of Massachusetts \\ Directed by: Professor George N. Wade
}

The effects of estradiol and progesterone on food intake, body weight, carcass adiposity, and acipose tissue lipoprotein lipase (LPL) activity were investigated in weanling rats. Treatment with estradiol benzoate (EB) reduced body weight gain in ovariectomized (OVX) weanlings as it does in adults. However, other responses to EB were atteruated or absent in prepubertal females. EB treatment did not reduce food intake, carcass adiposity, or adipose tissue LPL activity. This impaired responsiveness to EB may be due to decreased levels of cytoplasmic estrogen receptors in liver and adipose tissue (but not hypothalamus) in weanlings.

On the other hand, responsiveness to progesterone was adult-like in weanlings. Treatment of OVX, EB-primed prepubertal females with progesterone increased food intake, body weight gain, and carcass adiposity. This adult-like responsiveness to progesterone was associated with adult-like levels of adipose tissue progestin receptors. However, progesterone treatment did not increase adipose tissue LPL activity in weanlings, indicating that changes in LPL activity are 


\begin{abstract}
not necessary for progesterone-induced obesity.
These results confirm and extend previous findings of ovarian hormone effects on food intake and body weight regulation in prepubertal female rats. Furthermore, they suggest possible mechanisms by which estradiol and progesterone exert their effects.
\end{abstract}


TABLE OF CONTENTS

ACKNOWLEDGEMENTS

ABSTRACT

LIST OF TABLES

LIST OF FIGURES

Chapter

I. GENERAL INTRODUCTION

Ovarian Hormone Manipulations in Female Rats

Central Versus Peripheral Control Mechanisms $\cdot . \cdot \cdot 1$

Peripheral Sites of Hormone Action

Ovarian Hormone Effects in Prepubertal Female Rats $\cdot \cdot 4$

II. EFFECTS OF ESTRADIOL AND PROGESTERONE ON FOOD INTAKE,

BODY WEIGHT AND CARCASS COMPOSITION . . . ..... 10

Method. . . . . . . . . . . . 12

Results . . . . . . . . . . . . . . 13

Discussion ...................... 23

III. EFFECTS OF OVARIAN HORMONES ON ADIPOSE LPL ACTIVITY . . . 33

Method ............... 33

Results . . . . . . . . . . . . . 35

Discussion ............... 35

IV. CYTOPLASMIC ESTROGEN RECEPTORS IN ADIPOSE TISSUE . . . . 39

Method ............... 39

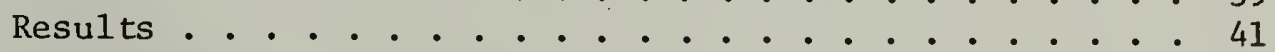

Discussion ............... 41

V. CYTOPLASMIC PROGESTIN RECEPTORS IN ADIPOSE TISSUE . . . 45

Method ............... 45

Results ............... . . 46

Discussion ............... . . 47

VI. GENERAL DISCUSSION .............. 50

The Effect of Estradiol on Body Weight. . . . . . . 51

The Paradox of Progesterone Treatment . . . . . . 52 
REFERENCES . • . . . . . . . . . . . . . 55

viii 


\section{LIST OF TABLES}

1. The Effect of Estrogen and Progesterone Administration on Naso-Anal Lengths in OVX Rats . . . . . . . . . . . . 17

2. The Effect of Estrogen or Progesterone Administration on Lee Indices in OVX Rats. . . . . . . . . . . . . 18

3. The Effect of Estrogen or Progesterone Administration on Carcass Composition in 35 Day 01d OVX Rats . . . . . . 20

4. The Effect of Estrogen or Progesterone Administration on Carcass Composition in 42 Day 01d ovx Rats . . . . . . 21

5. Correlation Coefficients between Lee Index and Percentage of Body Fat in 35 and 42 Day old Animals . . . . 23

6. Pearson Correlation Coefficients for Percent Carcass Components in 35 and 42 Day 01d Rats............. . . 31

7. Stepwise Multiple Linear Regression between Wet Weight and Fat, Water and Protein Components in 35 and 42 Day 01d Rat Carcasses . . . . . . . . . . . . . . . 
1. Food Intake of ovX Weanling Rats . . . . . . . . . 15

2. Body Weight Galn of ovX Weanling Rats . . . . . . . . . . . 16

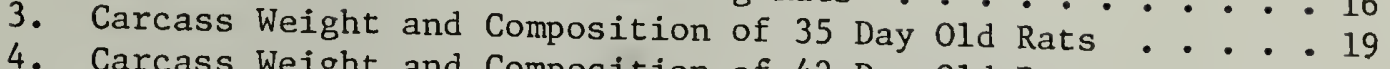

4. Carcass Weight and Composition of 42-Day-01d Rats . . . . 22

5. Correlation between Wet Carcass Weight and Body Lipid

in 35 Day Old ovX Rats . . . . . . . . . . . 28

6. Correlation between Wet Carcass Weight and $\% \dot{\text { Body Lipid }}$ in 42 Day O1d OVX Rats . . . . . . . . . . . 29

7. Parametrial Adipose Tissue LPL Activity in 32 Day old OVX Rats ..................... 36

8. Cytoplasmic Estrogen Binding Sites in Parametrial Adipose Tissue. . . . . . . . . . . . . . . . 42

9. Cytoplasmic Progestin Binding Sites in Parametrial Adipose Tissue. . . . . . . . . . . . . . 48 


\section{H A P \\ GENERAL INTRODUCTION}

Gonadal steroids have important effects on body weight, particularly body fat levels, in a number of mammalian species (Wade, 1976). In female rats, body weight and adiposity (amount of body mass devoted to fat stores) fluctuate dramatically in response to changes in reproductive status. These observed changes are due primarily to changes in circulating levels of estradiol, although progesterone has secondary modulating influences (Wade, 1975; 1976). For example, during the estrous cycle when estrogen levels are high (proestrus), body weight is reduced (Brobeck, Wheatland and Strominger, 1947; ter Haar, 1972), whereas at diestrus, when estrogen levels are reduced, body weight is increased (ter Haar, 1972).

\section{Ovarian hormone manipulations in female rats}

These changes can be mimicked by experimentally altering hormone levels. In adult female rats, ovariectomy (OVX) increases body weight, an effect which can be reversed by estradiol treatment (Mueller and Hsaio, 1980; 1981; Wade, 1975). Treatment of ovX rats with progesterone alone has no effect on body weight, but given concurrently with estradiol or to intact rats, progesterone increases body weight (Galletti and Klopper, 1967; Hervey and Hervey, 1976; Wade, 1975; Gray and Wade, 1981). Although several carcass components are altered by manipulations of ovarian hormones, the greatest change is observed in 
total carcass fat content (Galletti and Klopper, 1967; Gray and Wade, 1981; Hervey and Hervey, 1976; Leshner and Collier, 1973). OVX may double carcass fat content; estradiol treatment reverses the effect of gonadectomy on adiposity. Progesterone treatment to ovx, estradiol-treated animals reverses the estrogen-induced effect, leading to an increase in the total fat content.

Steroid-induced changes in body weight and adiposity usually are accompanied by fluctuations in food intake (Wade, 1976). OVX results in a transient hyperphagia which is reversed by estradiol treatment (Tarttelin and Gorski, 1973; Zucker, 1969). Progesterone alone has no effect on food intake (Hervey and Hervey, 1966; 1967), but when administered concurrently with estradiol to ovX females, it increases feeding (Gray and Wade, 1981; Hervey and Hervey, 1967; Wade, 1975; Zucker, 1969). One might note that ovarian hormones also affect locomotor activity in a predictable manner. Running-wheel activity is permanently suppressed in OVX females (Wang, 1923). Estradiol treatment increases locomotor activity (Mook, Kenney, Roberts, Nussbaum, and Rodier, 1972), and progesterone inhibits this effect (Roberts, Kenney and Mook, 1972).

\section{Central versus peripheral control mechanisms}

Until recently, it was assumed that ovarian hormones acted directly on the brain to alter food intake which, in turn, resulted in the changes in body weight (e.g., Wade, 1976). The hypothalamus is an important site of gonadal hormone action (e.g., Wade and Gray, 
1979). Steroid binding sites for both estrogens (Eisenfeld, 1970; Eisenfeld and Axelrod, 1965) and progestins (Maclusky and McEwen, 1978) have been demonstrated in this area. Intracerebral implants of estradiol placed in the ventromedial hypothalamus (VMH) decrease food intake and body weight in OVX rats (Janowiak and Stern, 1974; Nunez, Gray and Wade, 1980; Wade and Zucker, 1970a). Nonetheless, while estradiol may act on the VMH to depress eating, ovariectomy increases, and estradiol treatment decreases, food intake and body weight in rats with large VMH lesions (Beatty, O'Brient, and Vilberg, 1975; King and Cox, 1973).

Under some circumstances, body weight and composition changes that are observed following ovarian steroid treatment are not accompanied by changes in food intake (Wade and Gray, 1979): Treatment of intact female rats with progesterone may result in increased body weights even when progesterone-induced hyperphagia is prevented (Hervey and Hervey, 1968). Second, it has been reported that ovx rats must be restricted to $80 \%$ of their presurgical ad lib food comsumption in order to prevent the increases in body weight gain (Roy and Wade, 1977). Therefore, hyperphagia is not necessary for either progesterone- or ovariectomy-induced weight gains.

Roy and Wade (1977) also have shown that the hypophagia observed following estradiol treatment is not sufficient to produce the normally observed, estrogen-induced reductions in body weight. In my own work I have observed that females maintained in constant bright light show a decrease in body weights and adiposity in response to estradiol 
treatment without a concurrent decrease in food intake (Schwartz, unpublished results).

These findings indicate that under certain conditions, changes in regulatory behaviors following ovarian steroid treatment may not be of critical importance for the observed changes in body weight and adiposity (Wade and Gray, 1979). Rather, ovarian hormones may act directly on peripheral metabolic tissues, such as adipose tissue and liver, in determining body weight and composition. Changes induced by hormonal actions on metabolic processes also may be important in modulating feeding, because food intake is sensitive to changes in the availability of metabolic fuels (Friedman and Stricker, 1976).

\section{Peripheral sites of hormone action}

Since adiposity is greatly affected by manipulations of gonadal hormones, it is conceivable that adipose tissue might serve as a peripheral metabolic site of gonadal hormone action. According to the current model of steroid hormone action (Gorski and Gannon, 1976; Gorski, 1980; O'Malley and Means, 1974; Yamamoto and Alberts, 1976), hormones are carried in the blood to various tissues where they passively diffuse into all cells. In target cells, a hormone-specific receptor protein is found initially in the cytoplasm of the cell. Upon interacting with the steroid, the steroid-receptor complex becomes "activated." The activated complex moves into the nucleus where it associates with the chromatin, either the DNA or chromosomal proteins, or both. These nuclear-receptor complexes alter the rate of synthesis 
of various RNA species. The RNA molecules, in turn, control the synthesis of the proteins which mediate the tissues' physiological responses. Thus, in order for a tissue to be considered as a target tissue, it should contain (a) specific, high affinity binding si.tes for the hormone; (b) nuclear accumulation of the hormone-receptor complex, and (c) hormone-induced changes in RNA and protein synthesis.

Rat adipose tissues contain high-affinity, specific cytoplasmic binding sites for 17ß-estradiol (Wade and Gray, 1978). Although binding is seen in all fat pads examined, receptor concentrations are highest in parametrial (gonadal) fat pads. An accumulation of labelled hormone in the nuclei of adipose tissue cells following an injection of $17 \beta-\left[{ }^{3} \mathrm{H}\right]$ estradiol also has been demonstrated (Gray, Dudley and Wade, 1981). Although hormone-induced changes in RNA synthesis have not yet been demonstrated, at least one protein is modulated by estradiol, namely progestin receptor (Gray and Wade, 1979). In OVX rats, treatment with estradiol benzoate (EB) has been shown to induce cy toplasmic progestin receptors in all fat pads examined (Gray and Wade, 1979).

In addition to adipose tissue, rat liver contains cytoplasmic estrogen receptors (Eisenfeld and Aten, 1979). Translocation from the cytoplasm to the nucleus has been demanstrated following both in vivo estradiol treatment (Aten, Weinberger and Eisenfeld, 1978) and under in vitro exchange assay conditions (Eisenfeld, 1980). Gonadal hormone treatment has been shown to alter hepatic RNA and protein synthes is (Kurtz, Sippel and Feigelson, 1976; Roy, McMinn and Biswas, 1975). Thus, these data support the hypothesis that both adipose 
tissue and liver are most likely ovarian hormone target tissues.

How might changes in peripheral metabolism in response to ovarian hormones contribute to changes in behavior and body weight regulation? Both estradiol and progesterone have significant effects on the production and storage of lipids by liver and adipose tissues, respectively. Both steroids modulate adipose tissue lipoprotein lipase (LPL) activity, an enzyme which is essential for adipocyte triglyceride uptake (Robinson; 1970). One way ovarian hormones may exert their effects is via changes in this enzyme (Wade and Gray, 1979): OVX increases adipose tissue LPL activity whereas estradiol treatment reduces enzyme activity by $75-80 \%$ in OVX rats (Gray and Wade, 1980; Hamosh and Hamosh, 1975). Progesterone alone has no effect on adipose tissue LPL activity in OVX rats, but in the presence of estradiol (e.g.,estrogen-treated OVX rats or gonadally intact rats), progesterone treatment significantly increases adipose LPL activity (Gray and Wade, 1980; Gray and Wade, 1981; Hamosh and Hamosh, 1975; Kim and Kalkhoff, 1978; Steingrims dottir, Brase1 and Greenwood, 1980). Ovarian hormones also may act on the liver directly to increase hepatic lipoprotein synthesis (Watkins, Fizette and Heimberg, 1972), including certain apolipoproteins which serve as cofactors for LPL (Kim and Kalkhoff, 1978).

Food intake might also be modulated by ovarian hormone-induced changes in circulating metabolic fuels. It has been suggested that estradiol may decrease food intake by increasing the availability of triglycerides through increased hepatic production and reduced LPL 
activity (Wade and Gray, 1979). Although it has since been shown that neither hyperlipemia nor impaired removal of triglyceride can account for the EB-induced hypophagia (Ramirez, 1980), other hormoneinduced shifts in metabolic fuels may still influence the changes observed in feeding.

\section{Ovarian hormone effects in prepubertal female rats}

The prepubertal female rat is an ideal natural system in which to investigate direct metabolic effects of ovarian hormones. In general, gonadal hormones have been shown to induce adult-like effects on body weight. Estradiol depresses body weight gains in ovx weanlings (Wade, 1974; Zucker, 1972), and progesterone treatment increases body weight in intact young females (Ross and Zucker, 1974). These effects, however, are relatively modest as compared to the effects observed in adults (Wade, 1976). One factor contributing to this attenuated response is that hormone-induced changes in body weight occur without changes in food intake. Injecting oVX weanlings with adult doses of EB does not suppress eating until approximately 40 days of age (Wade, 1974). This is about the same time that endogenous estradiol first influences eating in intact females (Wade and Zucker, 1979b). Similar1y, progesterone injections do not stimulate food intake in intact weanlings until puberty (Ross and Zucker, 1974).

These findings suggest that in developing female rats, hormoneinduced changes in metabolic processes may be more important than changes in ingestive behaviors in determining body weight regulation. 
One goal of the research was to examine more closely the development of gonadal hormone effects on body weight and food intake in prepubertal female rats. The effects of hormone manipulations on carcass composition, especially body fat content, also were examined.

Explanations concerning the development of regulatory responsiveness to ovarian hormones have focused primarily on neural control mechanisms. One hypothesis is based on the lipostatic model of feeding (Kennedy, 1953; 1967; 1969). According to this model, in adult rats the VMH monitors fat content and adjusts feeding behavior so that body fat levels are maintained within a restricted range. Kennedy (1967; 1969) has proposed that in weanling animals 1ipostatic regulation by the VMH is fully mature. However, due to the actions of pituitary growth hormone (GH), the amount of fat in these rats is too low to trigger the lipostat (Kennedy, 1969). Consequently, since estradiol alters eating by this 1ipostatic mechanism, its effects are absent in immature females (Wade, 1976).

There are several weaknesses in this explanation. First, the lipostatic model itself has been disputed on several grounds (Friedman and Stricker, 1976; Nance, 1980). For example, Friedman and Stricker (1976) point out that body fat stores probably influence feeding only indirectly by altering the immediate supply of utilizable metabolites that result from changes in lipogenesis and lipolysis. Second, a case has already been made for the fact that estrogen may alter food intake independent of the VMH. Finally, although GH probably does play an important role in ovarian-hormone effects of prepubertal rats, the 
mechanism which Kennedy suggests is unlikely given that the VMH is functional for certain aspects of feeding behavior (Nance, 1980). Rather than neural target sites, GH may alter metabolic processes in peripheral gonadal steroid target tissues, thereby changing the availability of utilizable metabolic fuels important in the regulation of feeding.

Given the above considerations, rather than focus on neural control mechanisms, it seemed more useful to examine peripheral metabolic mechanisms by which ovarian steroids might affect food intake and body weight. By studying adipose tissue I hoped to determine whether mechanisms by which gonadal hormones influence adult regulatory patterns could account for the effects observed in the developing rat. To this end, I examined both estrogen and progestin receptor binding systems and LPL activity in adipose tissue of prepubertal female rats. 


\section{H A P T E R I I \\ EFFECTS OF ESTRADIOL AND PROGESTERONE ON \\ FOOD INTAKE, BODY WEIGHT AND CARCASS COMPOSITION}

The effects of gonadal hormones on body weight are less clear cut in the prepubertal as opposed to the adult female. While several early studies found estrogens to be effective in reducing body weights of immature female rats (Grunt, 1964; Ramirez and Sawyer, 1965; Smith, 1961 ; Smith and Davidson, 1968), later findings suggested that fluctuations in gonadal steroid levels had no influence on body weight (Ber, 1972; Wade and Zucker, 1970b). A reevaluation of these latter studies, in addition to several more recent studies (Dubec, 1974; Ross and Zucker, 1974; Ross and Tarttelin, 1978), support the earlier findings that gonadal hormones may affect body weight prior to puberty. Factors such as dosage of hormone administered, statistical methods employed (e.g., Ross and Tarttelin, 1978), and lack of proper control groups may contribute to the conflicting results. Similarly, although Rothchild (1967) and Galletti and Klopper (1964) found progesterone to have no effect on body weight, in a more recent study (Ross and Zucker, 1974), progesterone treatment effectively increased body weights of prepubertal females.

In contrast, it is fairly-well established that ovarian hormones given prepubertally do not alter eating (Mueller and Hsiao, 1980; Ross and Zucker, 1974; Sieck, Nance, Ramaley, Tayler and Gorski, 1977; Wade, 1974; Wade and Zucker, 1970b; Zucker, 1972). Thus, in ovX prepubertal 
females, estrogen-induced decreases in body weight are not accompanied by decreases in eating. Similarly, weight gains of intact immature females treated with progesterone occur independently of increased food consumption. These findings strongly suggest that ovarian hormones act directly on metabolic processes involved in body weight regulation.

The period prior to puberty is characterized as a time of rapid somatic and skeletal growth (Kennedy, 1969; Mueller and Hsaio, 1980; Ross and Tarttelin, 1978; S1ob, 1972; Widdowson and McCance, 1960): After weaning, rats eat more (in proportion to their body weights), gain weight faster, and increase body length more rapidly than sexually mature animals. Nonetheless, these animals are not obese relative to older animals (Mueller and Hsiao, 1980). Since growth hormone, which shows high levels at this time (Eden, Albertsson-Wikland, and Isaksson, 1978; Dickerman, Dickerman and Meites, 1972; Ojeda and Jameson, 1977), stimulates rapid growth of lean body mass and inhibits lipogenesis (Daughaday, 1979), one would expect little accummulation of body fat in prepubertal females. Based on these data, one might hypothesize that changes in body weight following estrogen treatment might not specifically affect adiposity since fat content is already low. Rather, a decrease in body weight might be a function of estrogen-induced changes on overall growth which would be reflected in all carcass components. Hormone-induced body weight effects also reflect changes in skeletal growth. In adult rats, ovariectomy induces both an increase in body weight gain and skeletal growth. Estrogen treatment prevents 
weight gain and change in skeletal growth (Mueller and Hsiao, 1980; 1981). Since the period prior to puberty is a critical time for skeletal growth, immature animals might be especially prone to estrogen's effect.

The purpose of this study was twofold: One goal was to replicate and extend the basic findings on the effects of ovarian hormones on food intake and body weight in prepubertal female rats. The second goal was designed to investigate whether ovarian hormones affect carcass composition and/or skeletal growth in a manner similar to that observed in adult rats.

\section{Method}

Animals. Female CD strain rats (Charles River Breeding Laboratories), 21 days of age at the start of the experiment, were individually housed in hanging cages and maintained on a $12 \mathrm{~h}$ light:12h dark cycle. Animals were OVX on Day 22 via bilateral, dorsolateral incisions under methoxyflurane anesthesia (Metofane). Purina rodent chow pellets and tap water were available at all times throughout the experiment.

Food intake, body weight and carcass composition. Starting at 25 days of age, food intake and body weight were monitored in 45 ovx females. Food intake, corrected for spillage, was measured daily to the nearest 0.1 , and body weight was measured to the nearest gram every other day. At 27 days of age, animals were divided into 3 groups ( $n=15)$, matched for mean body weight and food intake. Rats received daily subcutaneous injections $(0.05 \mathrm{ml})$ of either sesame oil vehicle, $2 \mu \mathrm{g} \mathrm{EB}$, or $2 \mu \mathrm{g} \mathrm{EB}$ 
plus $5 \mathrm{mg}$ progesterone.

After one week of hormone treatment, one-half of the animals from each group were given an overdose of sodium pentobarbital (Nembutal). The remaining animals were sacrificed after 2 weeks of hormone treatment. Carcass composition was analyzed on all animals by a modification of the method of Leshner, Litwin and Squibb (1972). Rats were shaved, eviscerated, weighed, and then dried to a constant weight at $75-85^{\circ} \mathrm{C}$. The dehydrated carcasses were finely ground in a Waring blender, and a homogeneous sample (approximately $0.5 \mathrm{~g}$ ) was used for subsequent analysis. Lipid was extracted with 2 X $10 \mathrm{~m} 1$ petroleum ether, and protein was dissolved in $20 \mathrm{ml} 0.3 \mathrm{~N} \mathrm{KOH}$. Water and fat content were calculated by weight differences. Protein content was determined by the method of Lowry, Rosebrough, Farr and Randall (1951).

Naso-anal leng ths were measured at 22, 34, and 41 days of age. Animals were lightly anesthetized with Nembutal and were laid out flat on their dorsal side. Outside calipers were used for the naso-anal meas urements .

Differences among groups were evaluated using a one-way analysis of variance unless otherwise noted. Newman-Keuls tests were used for post-hoc comparisons of means and were considered statistically significant if $\underline{\mathrm{p}}<.05$.

\section{$\underline{\text { Results }}$}

Food Intake. During the two weeks of hormone treatment, EB had no 
effect on food intake, but concurrent injections of progesterone increased intake (Fig. 1) (hormone treatment effect: $F_{2,18}=3.63$, $\underline{P}<.05$ and $F_{2,18}=8.35, \underline{P}<.01$, for Days $29-35$ and Days 36-42, respectively). Since there were no differences in food intake between animals sacrificed at 35 or 42 days of age, data from only the latter are shown.

Body weight. As in adults, EB treatment suppressed body weight gain and concurrent progesterone injections prevented this weight loss $\left(F_{2,18}=8.08, \underline{P}<.01\right)$. Comparable body weight results were obtained for animals sacrificed at 35 days of age. On days 35 and 42 , EBtreated animals again weighed less than the other two groups, and at 42 days of age, progesterone-treated animals weighed less than the oil-treated controls $\left(\mathrm{F}_{2,21}=8.47, \underline{\mathrm{P}}<.01\right.$ and $\mathrm{F}_{2,18}=21.16$, $\underline{\mathrm{P}}<.01$, for days 35 and 42 , respectively).

Body lengths. As predicted, by 42 days of age, naso-anal lengths of EB-treated animals were shorter than oil-treated $\underline{t}_{12}=2.16, \underline{\mathrm{p}}<.05$, one-tail) or EB-plus-progeste rone-treated $\left(\underline{t}_{12}=1.94, \underline{\mathrm{p}}<.05\right.$, onetail) animals ( Table 1 ). 


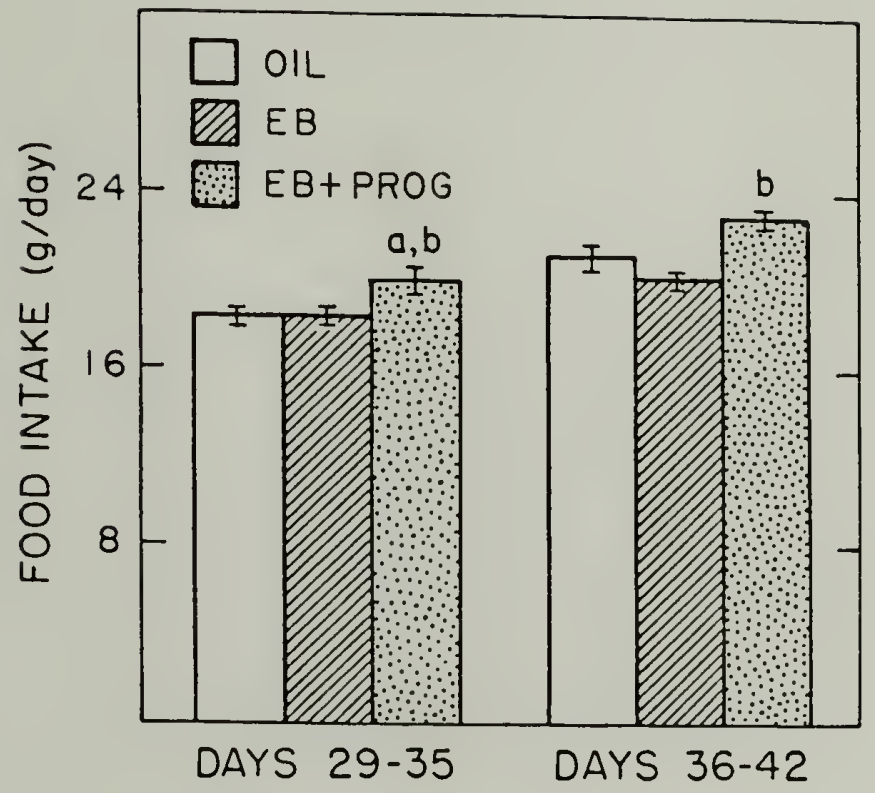

Fig. 1. Food intake of OVX weanling rats treated with sesame oil vehicle, EB (2 $\mu \mathrm{g} /$ day), or EB plus progesterone ( $5 \mathrm{mg} / \mathrm{day}) . \mathrm{a}$, $\mathrm{P}<.05$ versus oil-treated group; $\mathrm{b}, \mathrm{P}<.05$ versus EB-treated group; Newman-Keuls post hoc tests (mean \pm SEM). 


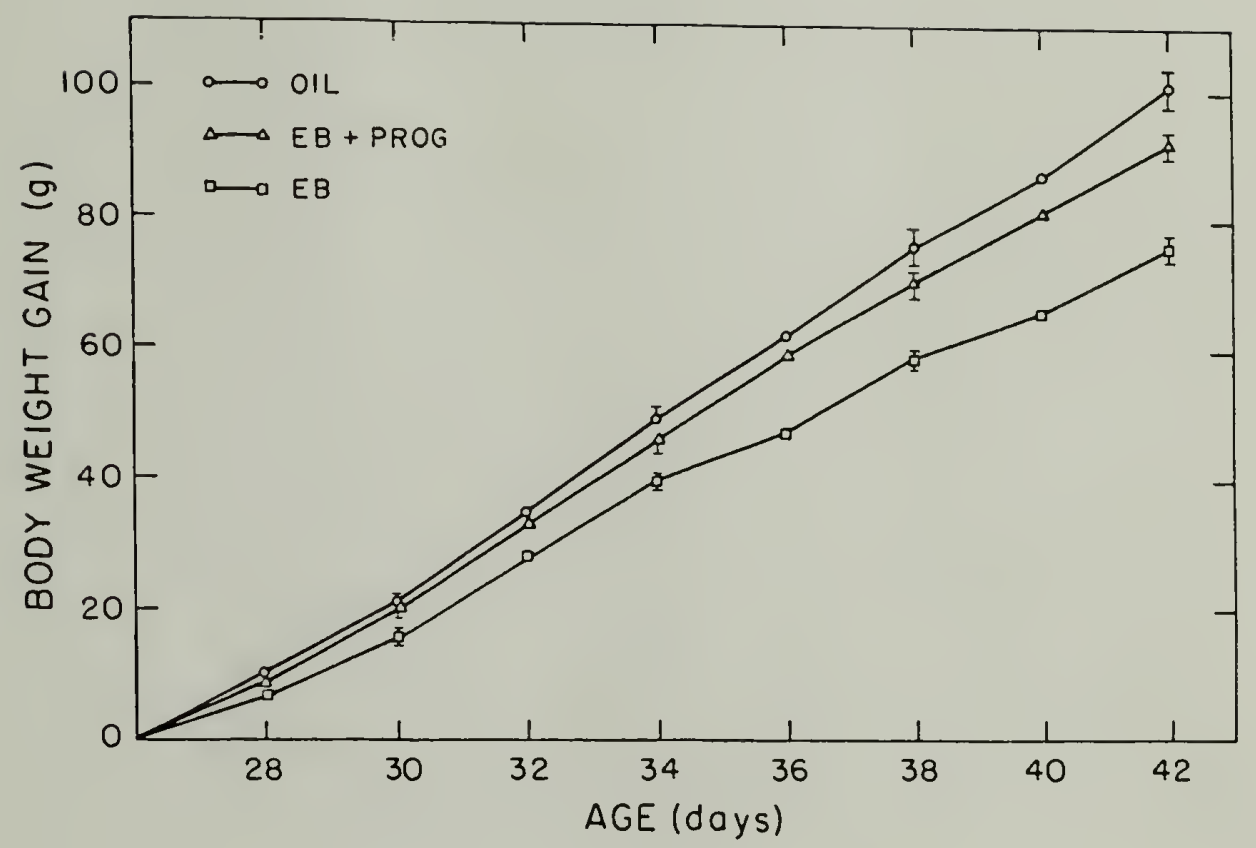

Fig. 2. Body weight gain of ovX weanling rats treated with sesame oil vehicle, EB $(2 \mu \mathrm{g} / \mathrm{day})$, or $\mathrm{EB}$ plus progesterone ( $5 \mathrm{mg} / \mathrm{day})$ (mean $\pm \mathrm{SEM}$ ). 
TABLE 1

THE EFFECT OF ESTROGEN OR PROGESTERONE ADMINISTRATION

ON NASO-ANAL LENGTHS IN OVX RATS

\section{NASO-ANAL LENGTHS (cm)}

\section{GROUP}

\begin{tabular}{|c|c|c|c|}
\hline DAYS OF AGE & OVX:OIL & ovX:EB & OVX:EB + PROG \\
\hline $\begin{array}{l}22 \\
(n=15)\end{array}$ & $12.0 \pm 0.1$ & $12.1 \pm 0.1$ & $12.1 \pm 0.1$ \\
\hline $\begin{array}{l}34 \\
(n=8)\end{array}$ & $15.3 \pm 0.2$ & $15.5 \pm 0.1$ & $15.6 \pm 0.2$ \\
\hline$\frac{41}{(n=7)}$ & $17.7 \pm 0.2^{*}$ & $17.0 \pm 0.2$ & $17.6 \pm 0.1^{*}$ \\
\hline
\end{tabular}

Lee Index. Body weight and naso-anal length can be used to compute a Lee Index, a measure which estimates the proportion of carcass fat to lean tissue (Bernardis and Patterson, 1968). The formula for the index is: 13/ body weight in grams/ (naso-anal length in $\mathrm{mm}$ ) $\times 10^{4}$. The higher the Lee Index, the greater the proportion of carcass fat. Since data for naso-anal length and body weight were available, Lee Indices for the animals were calculated which are shown in Table 2 . At 35 days of age, there was significant hormone treatment effect $\left(F_{2,21}=6.64, \underline{P}<.01\right)$. EB-treated animals showed a smaller Lee Index as compared with oil-treated animals $(\underline{P}<.05)$. By 45 days of 
age, there were no differences among the groups although EB-treated animals still had lower Lee indices.

\section{TABLE 2}

THE EFFECT OF ESTROGEN OR PROGESTERONE ADMINISTRATION ON LEE INDICES IN OVX RATS

\section{LEE INDICES}

DAYS OF AGE

$\begin{array}{llcr} & \text { OVX:OIL } & \text { OVX:EB } & \text { OVX:EB + PROG } \\ 22 & & \\ (\mathrm{n}=15) & 320.6 \pm 2.5 & 319.7 \pm 2.1 & 320.8 \pm 1.5 \\ 35 & & & \\ (\mathrm{n}=8) & 316.3 \pm 2.3^{*} & 304.6 \pm 3.0 & 309.7 \pm 2.0 \\ 42(\mathrm{n}=7) & 312.3 \pm 2.1 & 306.7 \pm 3.4 & 310.3 \pm 1.7\end{array}$

*

$\underline{\mathrm{P}}<.05$ versus $\mathrm{EB}$

All data are presented as mean \pm S.E.M.

Carcass composition. In 35 day old animals, progesterone-treated animals had less water than oil-treated animals and more fat than EBtreated animals $\left(F_{2,21}=4.94, \underline{\mathrm{P}}<.05\right.$ and $\mathrm{F}_{2,21}=4.28, \underline{\mathrm{P}}<.01$ for lipid and water, respectively) (Fig. 3). Treatment with estradiol had no effect on either wet carcass weight or on the percentage of any carcass component relative to the oil group. In terms of the absolute weight of the carcass components, progesterone treatment increased the number of grams of body lipid $\left(F_{2,21}=4.52, \underline{p}<.05\right)$ (Table 3$)$. 


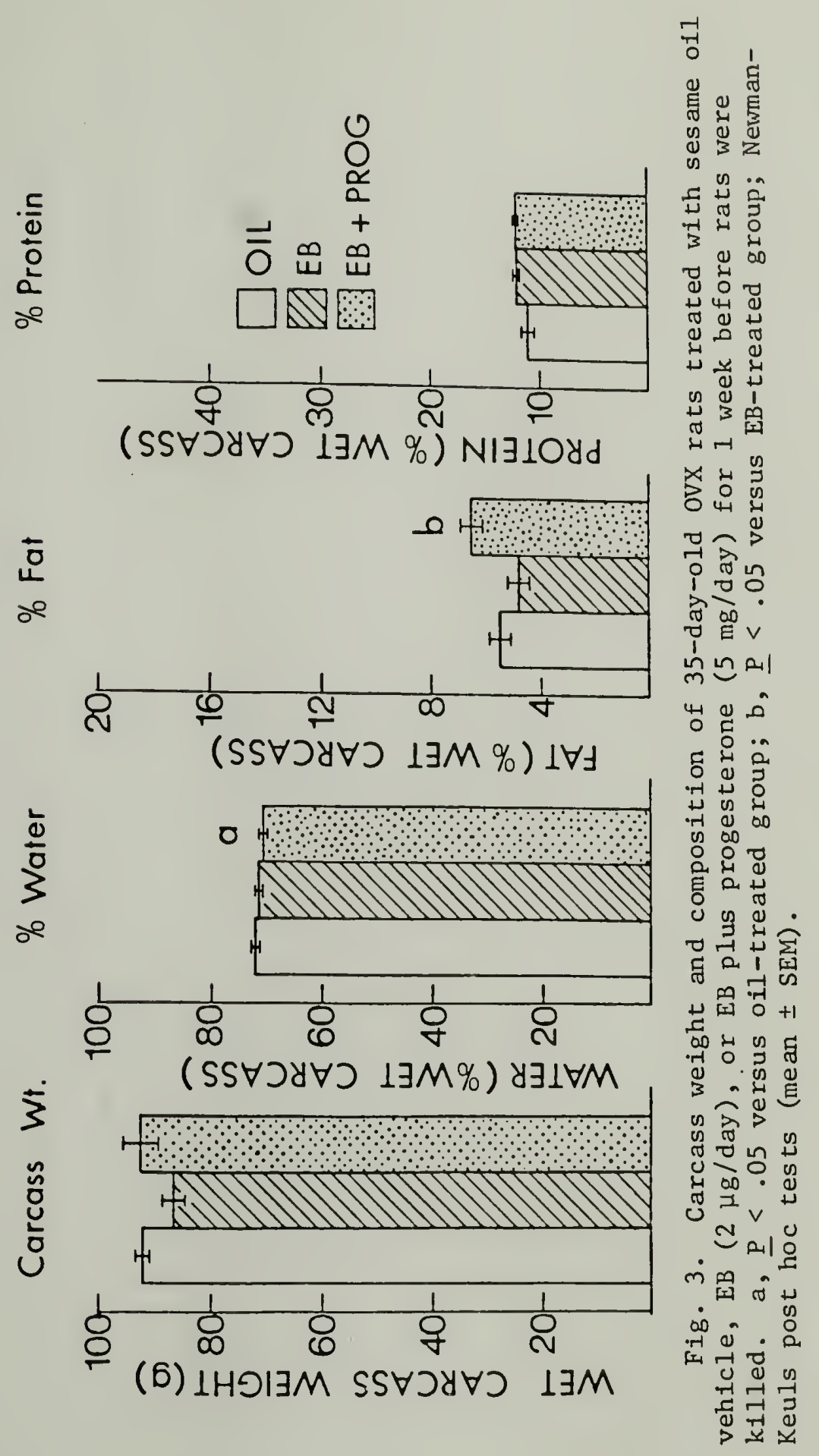


TABLE 3

THE EFFECT OF ESTROGEN OR PROGESTERONE ADMINISTRATION ON CARCASS COMPOSITION IN 35 DAY OLD OVX RATS

CARCASS ANALYSIS

TOTAL WET WEIGHT (g)
GROUP

OVX: OIL

OVX : EB

OVX:EB + PROG
WATER

$66.1 \pm 0.9$

$61.6 \pm 1.3$

$65.0 \pm 1.9$
FAT

$5.1 \pm 0.4$

$4.2 \pm 0.4$

$6.1 \pm 0.6^{*}$

\section{PROTEIN}

$10.0 \pm 0.6$

$10.2 \pm 0.3$

$11.0 \pm 0.4$

${ }^{*} \underline{\mathrm{p}}<.05$ versus OVX :EB group.

Al1 data are presented as mean \pm S.E.M.

In 45 day old animals, wet carcass weight $\left(\mathrm{F}_{2,18}=10.30, \underline{\mathrm{p}}<.01\right)$ as well as the percentages of lipid and water showed significant changes following hormone manipulations $\left(\mathrm{F}_{2,18}=4.53, \underline{\mathrm{P}}<.05\right.$ and $\mathrm{F}_{2,18}=11.17, \underline{\mathrm{P}}<.01$ for percent 1ipid and water respectively). EB treatment significantly decreased total carcass weight, but it had no effect on the percentage of fat or protein in the carcasses. In contrast, progesterone administration reversed the EB-induced change in total weight and significantly increased percent carcass fat. Treatment with EB alone or EB plus progesterone caused a small but significant decrease in percent water (Fig. 4).

Differences among the groups were observed in absolute weights of all the carcass components $\left(F_{2,18}=12.00, \underline{P}<.01, F_{2,18}=5.52\right.$,
$\underline{\mathrm{P}}<.05$ and $\mathrm{F}_{2,18}=5.01, \underline{\mathrm{P}}<.05$ for water, fat and protein, res- 
pectively). EB-treated animals had significantly less water and protein than oil-treated animals and less fat than EB-plus-progesterone-treated rats. Progesterone treatment caused a significant decrease in water as compared with oil-treated animals (Table 4).

TABLE 4

THE EFFECT OF ESTROGEN OR PROGESTERONE ADMINISTRATION ON CARCASS COMPOSITION IN 42 DAY OLD OVX RATS

\begin{tabular}{|c|c|c|c|}
\hline \multirow[b]{2}{*}{ GROUP } & \multicolumn{3}{|c|}{ TOTAL WET WEIGHT (g) } \\
\hline & WATER & FAT & PROTEIN \\
\hline OVX:OIL & $95.2 \pm 3.4$ & $10.3 \pm 0.4$ & $25.3 \pm 1.0$ \\
\hline OVX:EB & $77.1 \pm 2.4^{* *}$ & $8.9 \pm 0.6$ & $19.6 \pm 1.7^{*}$ \\
\hline OVX:EB + PROG & $86.5 \pm 1.9^{* *}$ & $11.5 \pm 0.7^{*}$ & $22.0 \pm 1.0$ \\
\hline
\end{tabular}

$\begin{aligned}{ }^{*} \mathrm{P} & <.05 \text { versus EB } \\ { }^{*}{ }^{*} \mathrm{P} & <.05 \text { versus OIL }\end{aligned}$

All data are presented as mean \pm S.E.M.

There has been some question concerning the validity of the Lee index as a measure of obesity (Stephen, 1980). Since the percentage of fat was already known, correlations were performed between the Lee index and percent lipid for all the animals. As seen in Table 4, a significant overall correlation was not found for either the 35 or 42 day old animals. However, within the hormone treatment groups, there was a significant correlation for the 35 day old estrogentreated animals $(\underline{t}=4.35, \underline{\mathrm{p}}<.01)$. In the 45-day-old EB-plus- 

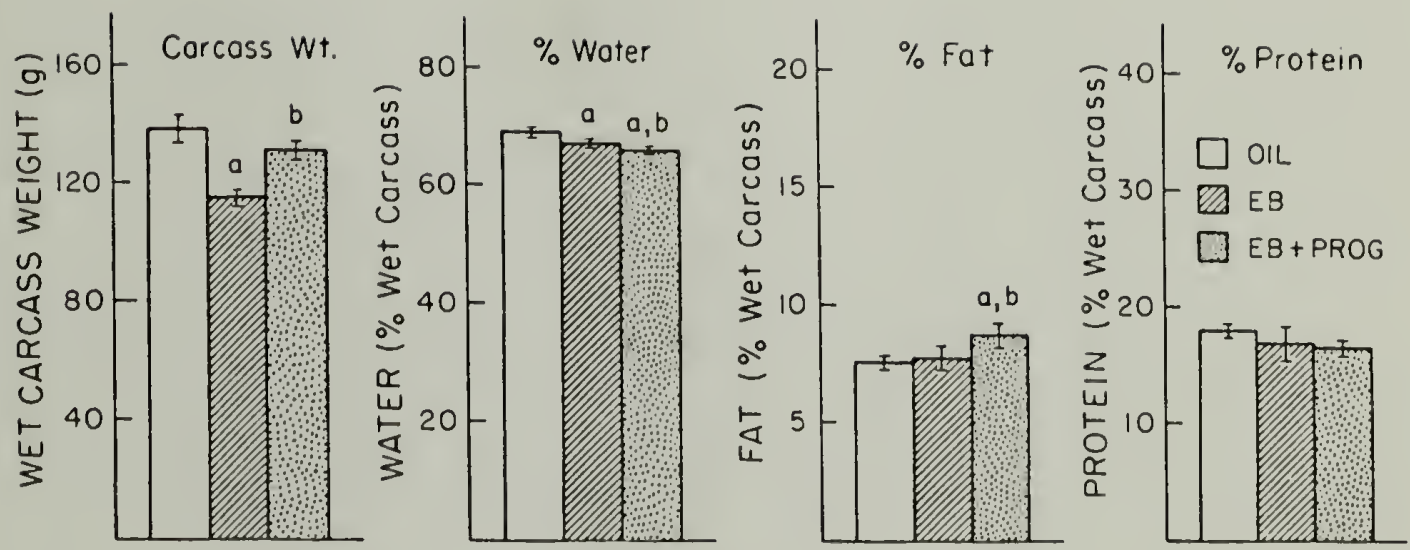

Fig. 4. Carcass weight and composition of 42-day-old ovX rats treated with sesame oil vehicle, EB $(2 \mu \mathrm{g} /$ day $)$, or EB plus progesterone $(5 \mathrm{mg} /$ day) for 2 weeks before rats were killed. a, $\underline{\mathrm{p}}<.05$ versus oil-treated group; $\mathrm{b}, \underline{\mathrm{P}}<.05$ versus EB-treated group; NewmanKeuls post hoc tests (mean \pm SEM). 
progesterone-treated animals, the correlation coefficient approached significance $(.05>\underline{\mathrm{P}}<.10)$.

TABLE 4

CORRELATION COEFFICIENTS BETWEEN LEE INDEX

AND PERCENTAGE OF BODY FAT IN 35 AND 42 DAY OLD ANIMALS

DAYS OF AGE

$\begin{array}{lllcc} & \text { OVX:OIL } & \text { OVX:EB } & \text { OVX:EB }+ \text { PROG } & \text { OVERALL } \\ 35 & \mathrm{r}=0.22 & \mathrm{r}=0.87^{*} & \mathrm{r}=0.28 & \mathrm{r}=0.32 \\ \begin{array}{l}42 \\ (\mathrm{n}=7)\end{array} & \mathrm{r}=0.14 & \mathrm{r}=0.36 & \mathrm{r}=0.72 & \mathrm{r}=0.26\end{array}$

GROUPS

OVX:EB + PROG OVERALL

${ }^{*} \underline{\mathrm{P}}<.01$ 
binding systems appear to be mature by 25 days of age (MacLusky, Chapta1, Lieberburg and McEwen, 1976; McEwen, Plapinger, Chapta1, Gerlach and Wallach, 1975; White, Hall and Lim, 1979), EB treatment does not decrease food intake or stimulate voluntary exercise of oVX weanlings as it does in OVX adult rats (Porterfield and Stern, 1974; Wade and Zucker, 1970b; Zucker, 1972). Both of these behavioral responses are mediated, at least in part, by direct hormone actions in the brain (Colvin and Sawyer, 1969; Nunez, Gray and Wade, 1980; Wade and Zucker, 1970a). Some neural action(s) of the estradiol receptorbinding system, either during or subsequent to cell nuclear binding, could be attenuated in weanling rats. For example, there is some evidence that the uterine shuttle system that binds sex steroids and convej's then to the nucleus may have different depletion and repletion rates in immature animals (Ferguson and Katzenellenbogen, 1977).

Another factor contributing to the reduced responsiveness to estradiol may be the presence of alphafetoprotein, a plasma estrogenbinding protein. This protein which has a high affinity for estradiol and estrone (Raynaud, 1973) plays an important role in the regulation of tissue estrogen levels during the period prior to puberty (Germain, Campbell and Anderson, 1978). During the first 3-4 weeks of postnatal life, much of the circulating estradiol is bound to alphafetoprotein, thereby retarding the interaction of the hormone with its receptors in target tissues (McEwen, 1978). As alphafetoprotein concentrations gradually decline (Raynaud, 1973; Raynaud, Mercier-Bodlard and Baulieu, 1971), there is a corresponding increase in the ability of 
exogenous estradiol to induce estrogenic responses (Germain et al., 1978). For example, it has been proposed that declining levels of alphafetoprotein account for the age-related increases in sensitivity to negative feedback effects of estrogen and for increases in the sensitivity of the reproductive tract to estrogen (Ojeda, Kalra and McCann, 1975; Germain et al., 1978). In the present study, alphafetoprotein also may have contributed to the reduced estrogen response prior to the 5th week of life. By binding exogenous estradiol, less hormone may have been available for neural and peripheral receptor binding systems.

The extreme leanness of immature rats may be an important factor in the inability of estradiol to affect feeding behavior. The $35-$ and 42-day -old OVX rat carcasses were only 5-8\% 1ipid (Fig. 2 and 3) compared with $14-16 \%$ in adult OVX rats (Gray and Wade, 1981; Leshner and Collier, 1973). Zucker (1972) has shown that lighter prepubertal rats respond later to the anorexic effects of estrogen relative to heavier animals. In adult ovX rats, lean animals typically show smaller reductions in food intake and body weight than do heavier animals in response to EB treatment (Rednick, Nussbaum, and Mook, 1973). Even a reduction of body weight by 48 hours of food deprivation may at tenuate the suppressing effects of estrogen on daily food intake (Sieck, Nance and Gorski, 1978).

The low percentage of fat in these animals also might explain the inability of estrogen to affect adiposity. It may be that a minimum amount of fat is necessary in order for the tissue to respond to 
estrogen treatment. In addition to the present results, it has been shown that in 35-day-old females, estrogen treatment (as compared with oil) has no effect on adipose tissue cell number or size (Simpson, personal communication). In adults, EB treatment results in a decrease in fat cell size (Salans, 1971; Steingrimsdottir et al., 1980).

Other metabolic demands occurring at this time such as those induced by GH might account for the decreased responsiveness. Hypophysectomized-OVX weanlings increase both their feeding and locomotor activity in response to exogenous estradiol (Porterfield and Stern, 1974; Wade and Zucker, 1970b). Administration of GH restores the refractoriness in these animals (Wade, 1974). While there is no evidence for direct actions of $\mathrm{GH}$ on neural steroid target tissues, the hormone may act on peripheral tissues to produce a variety of metabolic responses some of which might antagonize effects of estrogen on feeding and adiposity; for example, following administration, GH promotes the storage of metabolic fuels within the adipocyte (Goodman, 1981).

During the prepubertal period, animals are physiologically sensitive to dietary factors which can interfere with general physical growth and development; for example, Heggeness (1965) found that intermittent food deprivation in weanling rats results in increased body fat and decreased protein content although weight gain is similar to control animals. In postpubertal animals, no change in body $f$ at is observed. One factor contributing to these differences between 
pre- and post-pubertal animals may be that prior to puberty, there are major changes occurring in body composition. In male rats, before 35 days of age, there are dramatic changes in adipose tissue growth and metabolism (Hietanan and Greenwood, 1977). Assuming females are similar, one might predict given the findings of Heggeness that prior to 35 days of age, adipose tissue may be an important factor contributing to body weight control relative to other carcass components.

Since composition profiles were available for 35 (prepubertal) and 42 (postpubertal) day old animals, this hypothesis was examined. A correlation was performed between wet carcass weight and percent body fat in the two age groups (Fig. 5 and 6). Only in the younger animals is there a significant correlation $\left(r=.56, \underline{t}_{22}=4.52, \underline{\mathrm{p}}<.002\right)$. Thus, changes in percentage body fat account for a significant proportion of the variance in wet weight for the 35-day-old animals.

To determine to what extent all the carcass components contributed to the body weight variance, a correlation matrix and a stepwise multiple linear regression analysis were carried out for the two ages. The results from the analyses support the hypothesis (Table 6 and 7 ). In 35 day old animals, $32 \%$ of the variance could be accounted for by percent lipid content. Protein added less than $1.5 \%$ to the explained variance. In contrast, no one particular carcass component was a better predictor of body weight for the 42-day-old rats. Thus, these results demonstrate that at 35 days of age, body fat content is the best predictor of body weight relative to other carcass 


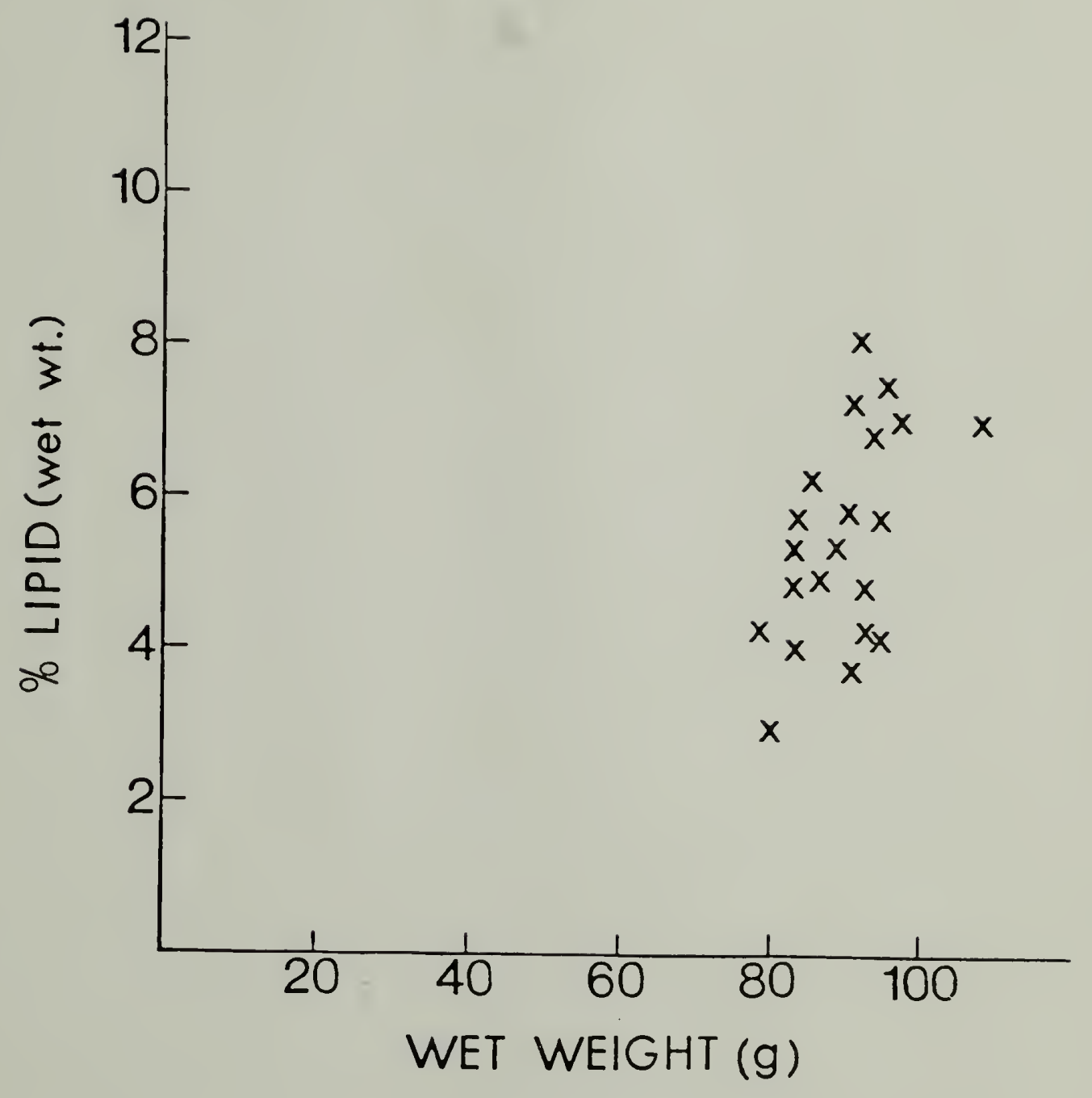

Fig. 5. Correlation between wet carcass weight and percent body lipid in 35-day-old rats. $r=.56$ ( $\underline{t}=4.52, \mathrm{P}<.01$ ). 


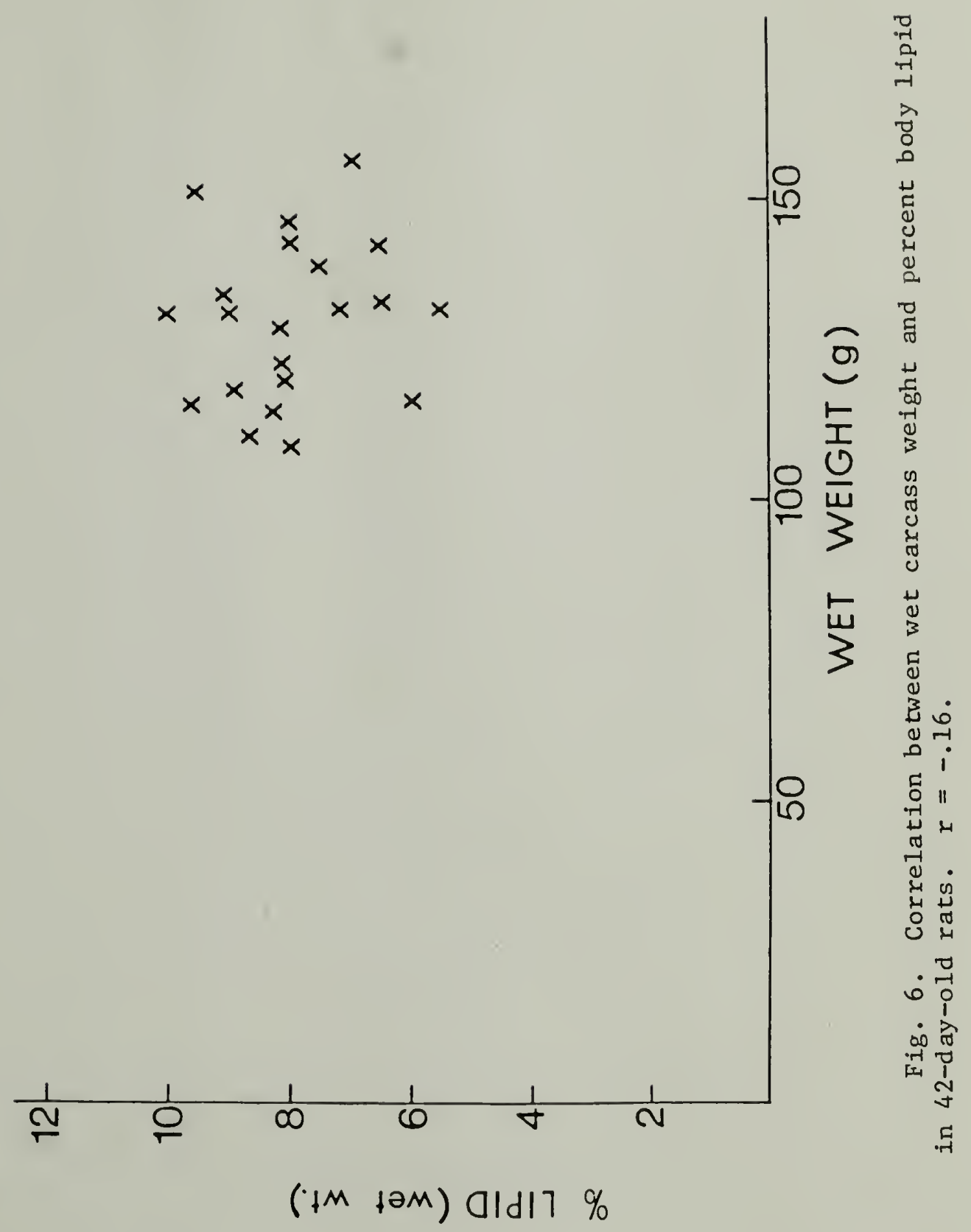


components.

In contrast to $\mathrm{EB}$, responses to progesterone with regard to food intake and carcass adiposity were similar to those observed in adults. These findings are somewhat surprising since in adults, progestins appear to play a secondary role in regulation of body weight by reducing or reversing the effects of estradiol (Wade, 1976). Thus, one would not expect to find effects of progesterone prior to estrogen-induced changes. In prepubertal animals, the situation appears to be somewhat different. It is possible that neural systems governing progesterone-induced behaviors may have a longer sensitivity threshold to hormone manipulations than systems involved in estrogen-dependent behaviors. For certain behaviors, this might carry an important adaptive value for the animals. For example, increases in food intake would be less detrimental to a rapidly growing animal than decreased food consumption.

Changes in food intake may have contributed to the increased adiposity observed following progesterone treatment. Intact adult females, maintained on an ad $\underline{1 \mathrm{ib}}$ or food restricted diet both gain weight in response to progesterone treatment, but the latter animals gain only about one-half as much (Hervey and Hervey, 1968). This difference in weight gain probably reflects a difference in fat content since increases in fat tissue accompany the increases in body weight (Galletti and Klopper, 1967; Hervey and Hervey, 1967; Krotkiewski and Bjorntorp, 1976).

While this explanation may be true, the opposite causal 
TABLE 6

PEARSON CORRELATION COEFFICIENTS FOR PERCENT

CARCASS COMPONENTS IN 35 AND 42 DAY OLD RATS

\section{DAYS OF AGE}

\begin{tabular}{lcc} 
& $\underline{35}$ & $\frac{42}{*}$ \\
WATER VERSUS FAT & $-.75^{*}$ & $-.81^{*}$ \\
\hline WATER VERSUS PROTEIN & -.29 & .08 \\
\hline FAT VERSUS PROTEIN & .26 & .29 \\
\hline \multirow{2}{\underline{P}<.001}{} & &
\end{tabular}

TABLE 7

STEPWISE MULTIPLE LINEAR REGRESSION BETWEEN WET WEIGHT AND FAT, WATER AND PROTEIN COMPONENTS IN 35 AND 42 DAY OLD RAT CARCASSES

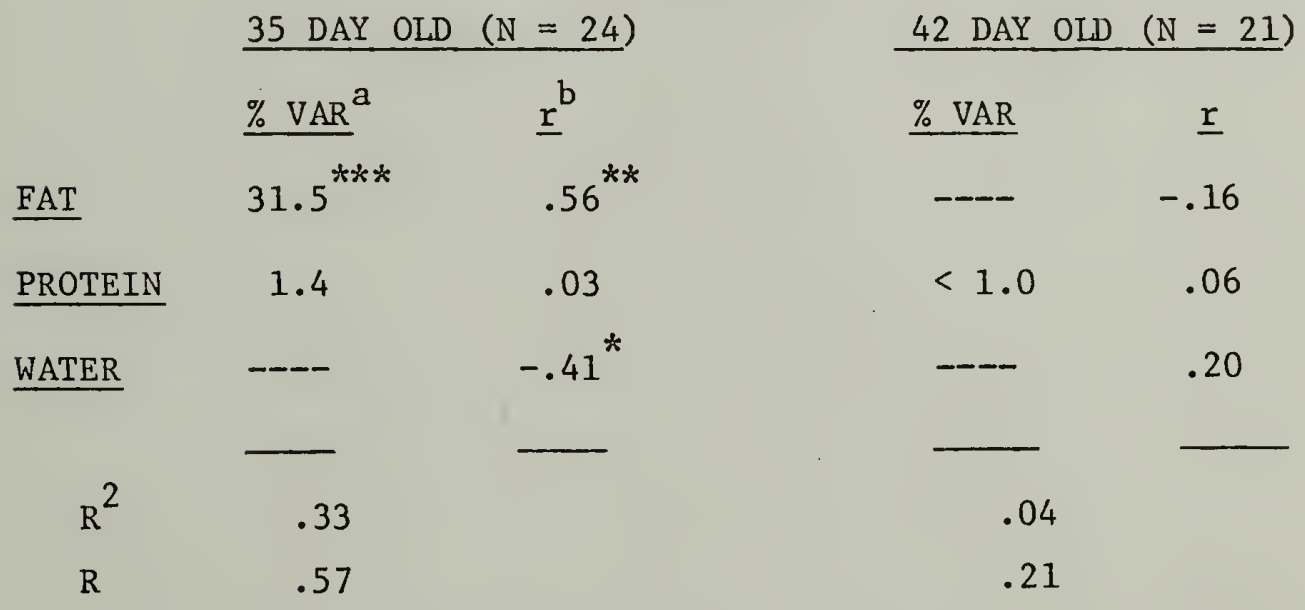

a percent of explained variance attributable to each component ${ }^{b}$ Pearson correlation coefficient for individual variables $\begin{aligned}{ }^{*} \underline{\mathrm{P}} & <.05 \\ * * \overline{\mathrm{P}} & <.01 \\ * * * \overline{\mathrm{P}} & <.001\end{aligned}$ 
relationship also may be argued. In other words, changes in adiposity may help explain the increased food intake following progesterone treatment. These changes in adiposity might be the result of direct actions of progestins on adipose LPL activity. 


\section{H A P T E R I I I}

EFFECTS OF OVARIAN HORMONES ON ADIPOSE TISSUE LPL ACTIVITY

Wade and Gray (1979) proposed that one way in which estradiol and progesterone may affect body weight is by altering the amount of fat stored via changes in adipose tissue LPL activity. These authors also suggested that ovarian steroids may alter food intake through changes in this enzyme. Changes in adipose LPL activity result in shifts in energy flux and caloric storage which are important factors in food intake regulation (Friedman and Stricker, 1976).

In the previous study, estrogen-treated animals showed a decrease in body weight but no change in food intake or adiposity. The progesterone-treated group, on the other hand, was responsive on all these measures. If peripheral mechanisms governing body weight and feeding in the prepubertal female operate in a manner similar to an adult's, than one would expect adipose LPL activity to be unresponsive to estradiol administration but to increase following progesterone treatment. The present experiment was designed to investigate this question.

\section{Method}

Animals. Animals were housed and maintained as described in the first experiment. Animals were OVX at 22 days of age and on Day 25 received daily injections of either oil $(n=7)$, EB $(2 \mu g ; n=7)$ or $E B$ plus progesterone ( $5 \mathrm{mg} ; \mathrm{n}=9)$ for one week. Twenty-four hours after the last injection (Day 32), animals were killed by decapitation. 
Assay conditions. LPL activity was detemined according to the method of Schotz, Garfinkel, Huebotter and Stewart (1970). Both parametrial fat pads were rapidly dissected and homogenized in $1 \mathrm{ml}$ homogenization medium containing $0.25 \mathrm{M}$ sucrose and $1 \mathrm{mM}$ EDTA (pH 7.4). Postmitochondrial supernatants were obtained by centrifuging the homogenates at $12,000 \mathrm{~g}$ for 15 minutes. The substrate emulsion was prepared by combining $1.8 \mu \mathrm{Ci}$ (carboxy $1-{ }^{14} \mathrm{C}$ ) triolein, $1.5 \mathrm{mg}$ lysolecithin, $36 \mathrm{mg}$ radioinert triolein, $3 \mathrm{ml}$ fasted human serum, $0.45 \mathrm{ml} 1 \%$ fatty acid poor bovine serum albumin, and $2.55 \mathrm{ml}$ $0.2 \mathrm{M}$ tris-HC1 $(\mathrm{pH} 8.0)$. This mixture was somicated on ice at $60 \mathrm{~W}$ for 4 minutes at 30 second intervals with a Branson sonifier equipped with a microtip. The substrate emulsion was activated at $37^{\circ} \mathrm{C}$ for 30 minutes. One hundred microliters of substrate was added to $100 \mu 1$ of the postmitochondrial supernatants. Duplicate samples were incubated for 30 minutes at $37^{\circ} \mathrm{C}$. Additional samples were assayed in the presence of $0.67 \mathrm{NaCl}$ to measure nonspecific LPL activity. The reaction was stopped by addition of $3.25 \mathrm{ml}$ of chloroform; methanol: heptane. Phase separation was facilitated by adding $1.05 \mathrm{ml}$ carbonate buffer ( $\mathrm{pH} 10.5)$. After centrifuging samples for 20 minutes (550 g) at room temperature, one $\mathrm{ml}$ of the upper phase containing released free fatty acids (FFA) was pipetted into a scintillation vial. After adding $12 \mathrm{ml}$ toluene-based scintillation fluid, the samples were counted at an efficiency of approximately $85 \%$.

Ten microliter aliquots of the postmitochondrial supernatants were analyzed for protein by the method of Lowry et al. (1951). Data 
are presented as $\mu$ mol FFA released per hour per mg protein.

Differences between groups were evaluated using Student's $t$ test and were considered statistically significant if $\underline{\mathrm{p}}<.05$.

\section{$\underline{\text { Results }}$}

Neither EB alone nor progesterone had any effect on parametrial adipose tissue LPL activity in weanling rats (Fig. 7). In adult ovx rats, this dose of EB causes a 75-80\% decrease in adipose tissue LPL activity (Gray and Wade, 1980; Gray and Wade, 1981).

\section{Discussion}

Unlike adult female rats, treatment with ovarian steroid hormones had no effect on adipose tissue LPL activity. In the previous study, at 32 days of age, EB-treated animals showed no difference in food intake or adiposity as compared with oil-treated animals. Thus, a failure to observe an estrogen-induced decrease in adipose LPL is not inconsistent with the hypothesis proposed by Wade and Gray (1979). On the other hand, OVX weanlings treated with both estrogen and progesterone showed increases in food intake and carcass lipid content. The same treatment, however, has no effect on adipose tissue LPL activity.

While this latter finding is somewhat surprising, it is not unprecedented. Observations in adult ovx rats treated with the antiestrogen nafoxidine support the present data (Gray and Wade, 1981). In nafoxidine-treated rats, progesterone increases carcass adiposity 


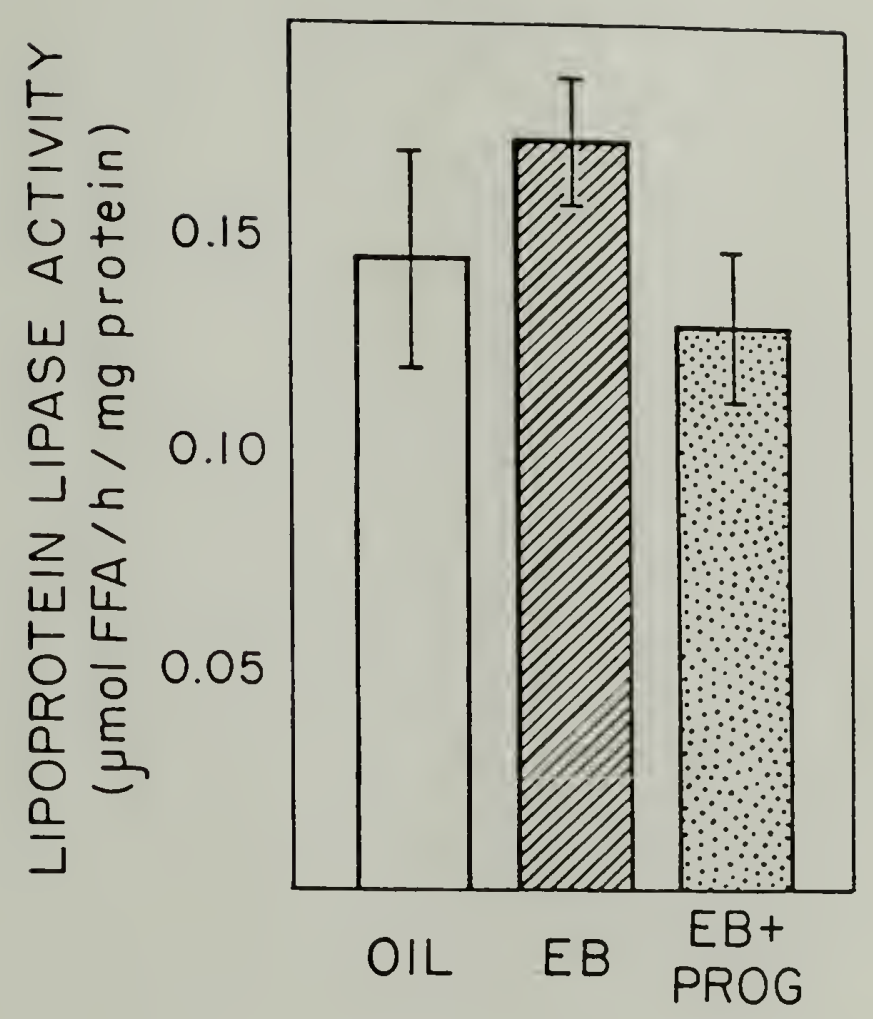

Fig. 7. Parametrial adipose tissue LPL activity in 32-day-old OVX rats treated with sesame oll vehicle, EB ( $2 \mu \mathrm{g} /$ day), or EB plus progesterone ( $5 \mathrm{mg}$ / day) for 1 week before rats were killed (mean \pm SEM). 
and food intake without affecting adipose tissue LPL activity. These findings indicate that changes in LPL activity are not necessary for progesterone-induced obesity.

Metabolic responses to ovarian steroids including adipose tissue LPL activity may be related to developmental changes in adipose tissue growth and metabolism. Hietanan and Greenwood (1977) have studied developmental changes in LPL activity and patterns of adipose growth in epididymal fat pads (male gonadal fat pad) of growing male rats. They found a rapid increase in LPL activity between Days 17 through 41 and a change in fat depot growth from cell hyperplasia to hypertrophy from Day 35 onward. If fat depots in female rats develop and differentiate in a similar manner, then the time at which increases in LPL activity become less pronounced (and more similar to adult levels of enzyme activity) corresponds approximately to the age at which female rats become sensitized to the anorexic effects of estrogens. The change in adipose tissue growth from cell number to cell size also occurs around the time of puberty. Thus, the effectiveness of ovarian steroids in altering LPL activity may be related to these developmental changes.

In OVX oil-treated animals, adipose tissue LPL activity (Fig. 7) was 3-4 times lower than in adult ovX females (Gray, 1980; Gray and Wade, 1980; 1981). These low LPL levels may be related to the small size of the fat cells (Gruen, Kava and Greenwood, 1980), since smaller fat cells have less LPL activity than larger cells (Bjorntorp et al., 1975). In order for gonadal hormones to produce an effect, a minimum 
level of enzyme activity may be necessary.

Adipose tissue LPL plays an important role in regulating fat cell size (Hietanan and Greenwood, 1977). Changes in enzyme activity and cell size parallel each other, with changes in LPL preceding the changes in size. For example, estrogen decreases both adipose LPL and fat cell size, and progesterone treatment reverses both of these effects (Salans, 1971; Steingrimsdottir et al., 1980). Based on these data, one would predict LPL to be unresponsive to a hormone treatment which has no effect on cell size. Thirty-five day old ovx rats show no decrease in fat cell size following estradiol treatment (Simpson, personal communication). Furthermore, estrogen treatment seems to have no effect on cell number at this age (Simpson, personal communication). Although the relationship between adipose tissue LPL and cell number is unclear, this latter finding is important since changes in cell number, rather than size, are important for adipose tissue growth at this time.

A causal link between ovarian steroid receptor sites and adipose LPL activity has not yet been demonstrated. Nonetheless, several high1y significant correlations suggest that the presence of steroid receptor binding proteins in adipose tissue are necessary in order for ovarian hormones to exert their effects on adipose LPL activity (Wade and Gray, 1979; Gray and Wade, 1980). It may be that prepubertal female rats have fewer receptor binding sites which would account for the ineffectiveness of ovarian hormones to alter adipose tissue LPL activity. 
CYTOPLASMIC ESTROGEN RECEPTORS IN ADIPOSE TISSUE

Although neural estrogen binding systems appear to be mature by 25 days of age (MacLusky et al., 1976; McEwen et al., 1975; White et a1., 1979), no one has determined whether there are specific estrogen binding sites in adipose tissues at this time. Estradiol's inability to alter adipose tissue LPL activity in prepubertal females may reflect a lack, or low concentration, of adipose estrogen receptors. In adult rats, the concentrations of estrogen and progestin receptors are correlated with their effectiveness in altering body weight and adipose tissue LPL activity (Wade and Gray, 1978; Gray and Wade, 1979).

\section{Method}

Animals. Animals were housed and maintained as in the previous experiments. OVX was performed either at 22 or 50 days of age. Five days following surgery animals were killed.

Tissue preparation. Animals were given an overdose of Nembutal. Parametrial adipose tissue was rapidly dissected, weighed to the nearest $0.1 \mathrm{mg}$, and minced with scissors. Tissues were homogenized in Teflonpestle glass homogenizers in a buffer containing $10 \mathrm{mM}$ Tris- $\mathrm{HCl}$, $1.5 \mathrm{mM}$ EDTA, $12 \mathrm{mM}$ momothioglycerol, and 10\% (vol/vol) glycerol, $\mathrm{pH} 7.4$ (TEMG buffer). Adipose tissue was homogenized at a concentration of $100 \mathrm{mg} / \mathrm{ml}$ buffer (55 day old animals) or in $1 \mathrm{ml}$ buffer (27 day old animals). This and all subsequent steps were carried out at $0-4^{\circ} \mathrm{C}$. 
Homogenates were centrifuged at $48,000 \mathrm{~g}$ for 30 minutes.

Estrogen receptor assay. Adipose tissue cytoplasmic estrogen binding was determined in 27- and 55-day-old ovx rats according to previously published methods (Wade and Gray, 1978). Nonspecific binding was determined by incubating high-speed supernatant with either radioinert estradiol or $11 \beta$-methoxy-17-ethyny 1-1,3,5(10)-triene-3,17ß-diol (R2858). R2858 was used as a competitor because unlike estradiol, it is not bound by alphafetoprotein (McEwen et al., 1975). Bound and free $17 \beta-\left[{ }^{3} \mathrm{H}\right]$ estradiol were separated by gel filtration on $5 \times 60 \mathrm{~mm}$ Sephadex LH-20 columns, equilibrated with TEMG, as described by Ginsburg et al., (1974), using the buffer as the eluent. Two hundred microliters of the incubate were pipetted into the column and washed in with $200 \mu 1$ TEMG. After 30 minutes, the protein peak was eluted into a scintillation vial with $700 \mu 1$ TEMG, and $12 \mathrm{ml}$ toluene-based scintillation fluid was added. After vigorous shaking, radioactivity was counted to a standard deviation of less than $1 \%$ in a Packard model 2425 scintillation counter at an efficiency of $55 \pm 1 \%$.

Specific binding, i.e., total binding (without radioinert R2858) minus nonspecific binding (with radioinert R2858) was computed as femtomoles of $\left[{ }^{3} \mathrm{H}\right]$ estradiol bound per mg protein. To determine the concentration of protein in the cytoplasmic fraction, $100 \mu 1$ aliquots of the high-speed supernatants were precipitated with $5 \mathrm{ml}$ ethanol. The precipitate was dissolved in $0.3 \mathrm{~N} \mathrm{KOH}$, and the protein concentration was determined according to the method of Lowry et al. (1951). 
Differences between groups were evaluated using Student's $\underline{t}$ tests and were considered statistically significant if $\underline{\mathrm{p}}<.05$.

\section{Results}

Specific $\left[{ }^{3} \mathrm{H}\right]$ estradiol binding was found in parametrial adipose tissue of both 27- and 55-day-old animals, but significantly less specific binding was observed in the younger animals (Fig. 8) $\left(\underline{t}_{11}=\right.$ $2.82, \underline{\mathrm{P}}<.05)$. It also should be noted that in 27-day-old animals, nonspecific binding with estradiol was significantly lower compared with R2858 ( $\left.\underline{\mathrm{t}}_{14}=2.21, \underline{\mathrm{P}}<.05\right)$.

\section{Discussion}

The lower concentration of adipose estrogen receptors in 27-dayold OVX rats may partially account for the inability of estradiol to alter adipose LPL activity, and, hence, to decrease adiposity. Since the difference in nonspecific binding with estradiol as compared with R2858 probably represents alphafetoprotein, this plasma protein also may contribute to the attenuated adipose tissue responses. By binding exogenous estradiol, less circulating estrogen may have been available for its specific binding sites in adipose tissue.

Hepatic receptor levels may be a factor in the decreased responsiveness to EB. The concentration of estrogen binding sites is several fold higher in the liver cytosol from adult females than from prepubertal female rats (Eisenfeld, Aten, Weinberger, Hasalbacker and Krakoff, 1976). In these animals, hepatic responses to estrogens, in- 


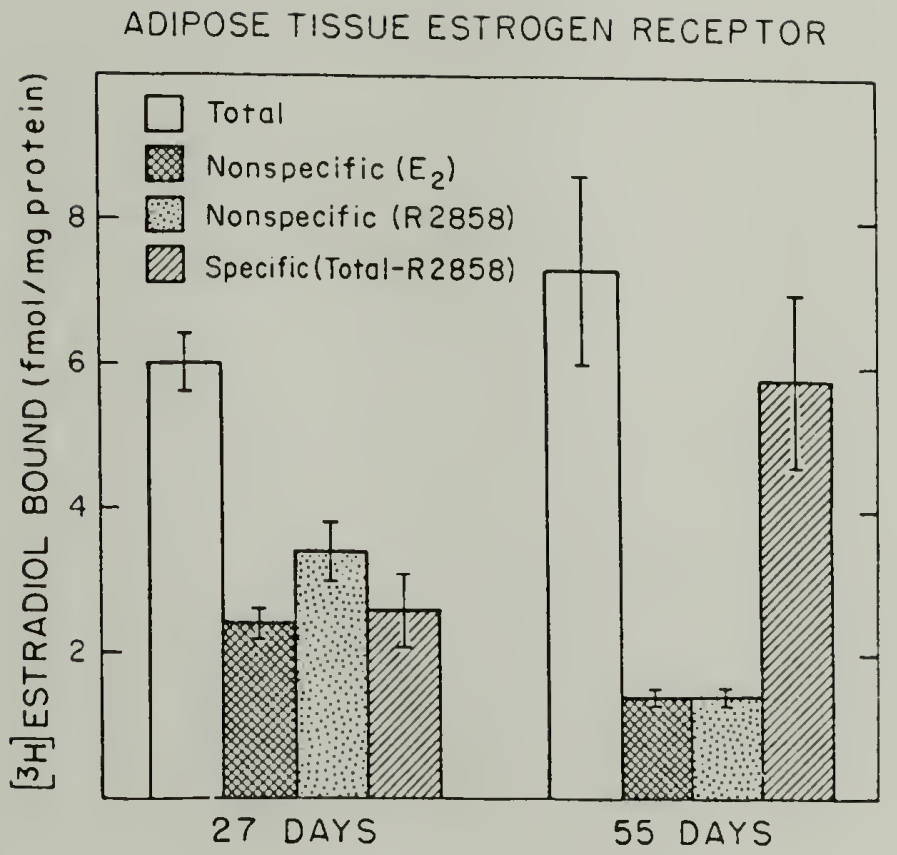

Fig. 8. Cytoplasmic estrogen binding sites in parametrial adipose tissue of 27- or 55-day-old rats (mean \pm SEM). 
cluding renin substrate production, are attenuated; in adults this plasma protein is greatly increased following estrogen treatment (Eisenfeld and Aten, 1979). Thus, estrogenic actions on hepatic lipid and lipoprotein production, some of which may be important for adipose tissue regulation, may be reduced in weanling rats. For example, certain apoproteins which serve as cofactors for adipose tissue LPL are lower in prepubertal animals than in adults (Parsch, Kim, Wiest and Schonfeld, 1980).

Although the values obtained in the prepubertal females most likely indicate a reduced estrogen receptor concentration, it is possible that the lower level also was obtained because a number of cytoplasmic estrogen receptors already were bound to endogenous estrogen and/or translocated within the nucleus. The metabolic clearance rate of estradiol is lower in 28-day-old rats as compared with adult rats (De Hertogh, Ekka, Vanderheyden and Hoct, 1970), so that even 5 days after ovx, significant circulating levels of estrogen may still be present. Furthermore, the adrenal also may produce significant amounts of estrogen in the young animal (Ojeda, Kalra and McCann, 1975; Weisz and Gunsalus, 1973). Thus, these endogenous sources of estrogen may have already occupied a number of binding sites, resulting in lower $\left[{ }^{3} \mathrm{H}\right]$ estradiol concentrations in adipose tissue.

There are several lines of evidence which rule out this possibility. First, there is no evidence that adrenal estrogens are biologically active (Ramaley, 1979). Moreover, there is disagreement as to 
whether the adrenal even produces significant amounts of estrogens (Knonibus and Wuttke, 1977; Meijs-Roelofs, Vilenbroek, De Jong and Welshen, 1973). Second, if endogenous circulating estrogen were competing for binding sites, then one would not expect target tissues to be responsive to exogenous hormone treatment in intact animals. However, estradiol treatment results in rapid uterine growth in intact immature females (Anderson, Peck and Clark, 1975; Clark, Anderson and Peck, 1973). Third, unlike adipose tissue or liver, other steroid target tissues such as hypothalamus (MacLusky, Chaptal and McEwen, 1976) and uterus (Clark et al., 1973) show adult levels of cytosol estrogen binding sites prior to puberty. These cytoplasmic receptor concentrations are obtained using either intact (Katzenellenbogen, 1979 for review) or 1-day-OVX animals (MacLusky et a1., 1979). Finally, cell nuclear estrogen receptor complexes are very low or not detectable in cortical tissue samples from 25-26-day-old female rats ovariectomized for 24 hours prior to sacrifice. This indicates that extensive occupation of cortical receptors by endogenous estrogen is not a feature in the immature female rat (MacLusky et al., 1979). One may assume that this is a common feature of all steroid target tissues. 


\section{CYTOPLASMIC PROGESTIN RECEPTORS IN ADIPOSE TISSUE}

In adult OVX rats, cytoplasmic progestin receptor concentrations in adipose tissue are very low (Gray and Wade, 1979). Treatment with estradiol, however, induces a rapid increase in the number of progestin binding sites (Gray, 1980). Since several estrogenic responses are attenuated in prepubertal rats, induction of progestin receptors also may be reduced. A low concentration of progestin receptors would help account for the lack of a progestin effect on adipose LPL activity (e.g., Gray and Wade, 1980). On the other hand, progesterone treatment is able to alter body lipid content and food intake in weanling animals. Hence, the number of progestin binding sites might be comparable to adult levels.

\section{Method}

Animals. Animals were housed and maintained as in the previous experiments. Animals were ovX and adrenalectomized (ADX) via bilateral, dorsolateral incisions under Metofane at 22 or 50 days of age. OVX-ADX rats were given ad libitum access to $0.15 \mathrm{M}$ saline. Two days following surgery, animals were treated with either EB (2 $\mu g /$ day) or sesame oil for 3 days at which time they were sacrificed.

Tissue preparation. Animals were given an overdose of Nembutal. Adipose tissue was prepared as described in the previous study.

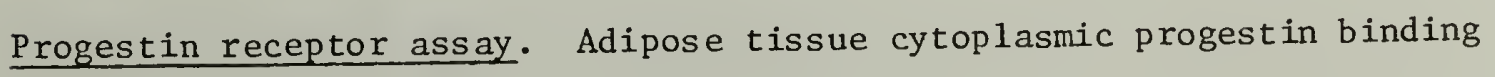


was assayed in 27- or 55-day-old rats by previously published methods (Gray and Wade, 1979) using the synthetic progestin [ $\left.{ }^{3} \mathrm{H}\right] 17 \alpha, 21-$ dimethy $1-$ 19-norpregna-4,9-diene-3,20-dione $\left(\left[{ }^{3} \mathrm{H}\right] \mathrm{R} 5020\right) . \mathrm{R} 5020$ binds to progestin receptors with a much higher affinity than does progesterone (Blaustein and Wade, 1978; MacLusky and McEwen, 1978; Raynaud, 1977). Thus, radioactively labelled $\mathrm{R} 5020$ is often used to characterize progestin binding in target tissues.

Aliquots of the high-speed supernatant were incubated with $2 \mathrm{nM}$ $\left[{ }^{3} \mathrm{H}\right] \mathrm{R} 5020$ alone or with a $10-, 100-$, or $1,000-$ fold excess of radioinert R5020 for 4 hours at $0^{\circ} \mathrm{C}$. Bound and free $\left[{ }^{3} \mathrm{H}\right] \mathrm{R} 5020$ were separated as in the previous experiment, except that the protein peak was eluted with $800 \mu 1$ TEMG. Because significant amounts of the R5020 seem to be absorbed to either plastic or glass incubation tubes, the total (bound plus free) $\left[{ }^{3} \mathrm{H}\right] \mathrm{R} 5020$ concentration of the incubates was determined by coumting $20 \mu 1$ aliquots at the end of the incubation. Results are expressed as femtomoles $\left[{ }^{3} \mathrm{H}\right] \mathrm{R} 5020$ specifically bound per mg protein. Protein concentrations of the cytoplasmic fractions were determined as in the previous experiment.

Differences between groups were evaluated using Student's $t$ test and were considered statistically significant if $\underline{\mathrm{P}}<.05$.

\section{$\underline{\text { Results }}$}

Unprimed 27-day-old OVX-ADX rats had a higher concentration of progestin binding sites than 55-day-old animals $\left(\underline{t}_{g}=2.71, \underline{\mathrm{p}}<.05\right)$. Following EB treatment, younger animals had slightly, but not 
significantly, more receptor sites than the older females (Fig. 9). Induction of progestin receptors, measured as an EB-primed/unprimed ratio was greater in adults (13.6-fold) than in younger animals (4.2fold) (Fig. 9). It has been shown previously (Gray and Wade, 1979) that in adult ovX rats there is a highly significant correlation between this ratio (EB-primed/unprimed) and the cytoplasmic estrogen receptor concentration in various fat pads. Unlike the uterus (Leavitt, Chan and Allen, 1977), there is no significant correlation between estrogen receptor concentration and the absolute magnitude of progestin receptor induction (EB-primed minus unprimed).

\section{$\underline{\text { Discussion }}$}

One of the factors contributing to the adult-like effects of progesterone on adiposity may be that adipose tissue progestin receptor levels, unlike estrogen receptors, are similar to (or greater than) adult levels.

Adult concentrations of adipose progestin receptors are present in prepubertal females, yet progesterone treatment is unable to alter adipose LPL activity. One reason for this finding may be that although 27-day-old rats show adult levels, induction of progestin receptors by EB treatment is reduced when compared with adult females. In adults, progesterone's effect on adipose tissue LPL activity is dependent on the presence of estradiol (Gray and Wade, 1980; Hamosh and Hamosh, 1975). The adipose tissue LPL response to progesterone treatment could depend not only on the presence of progestin binding sites, but also 


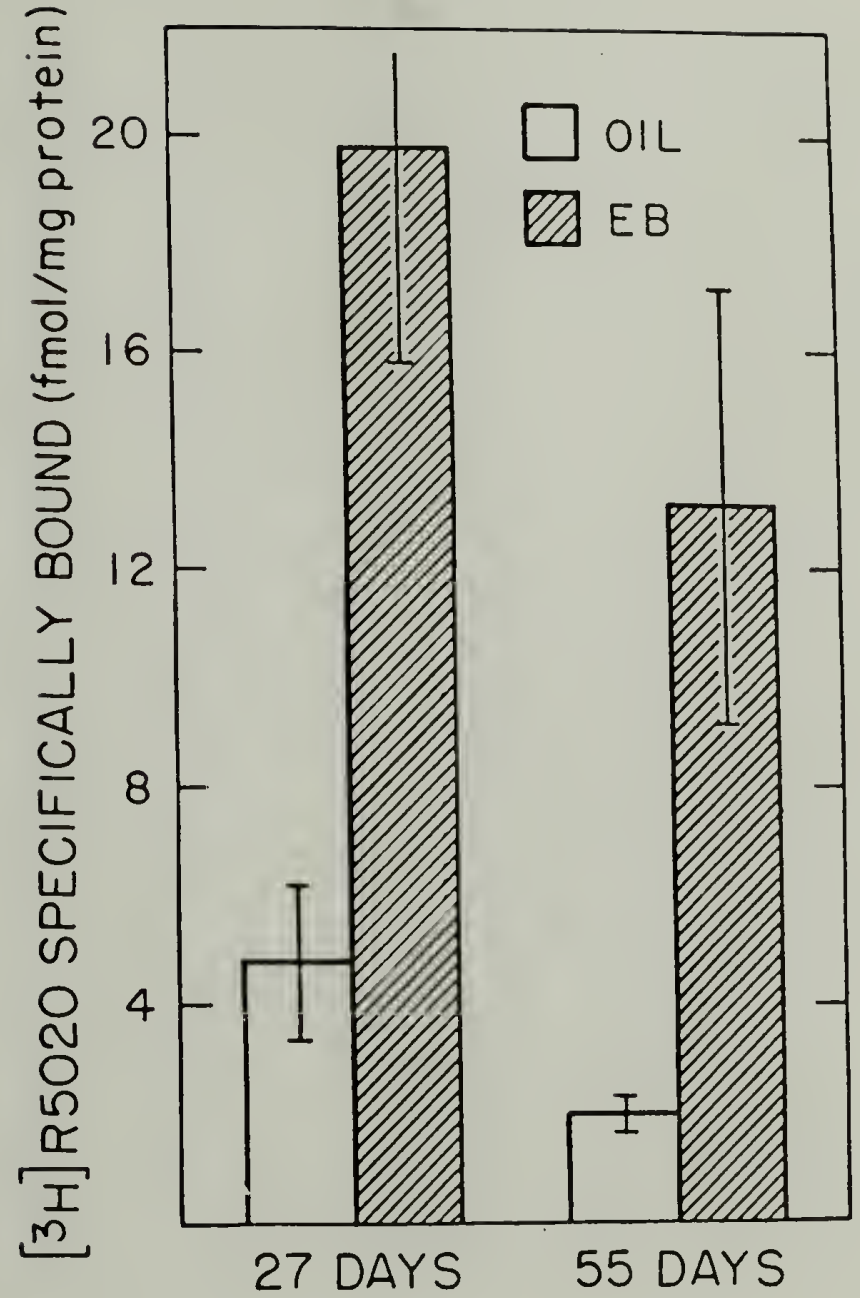

Fig. 9. Specific cytoplasmic progestin binding sites in parametrial adipose tissue of 27- or 55-day old ovx rats. Animals were treated with sesame oil vehicle or $\mathrm{EB}(2 \mu \mathrm{g} / \mathrm{day})$ for 3 days before they were killed (mean \pm SEM). 
on other actions of estradiol. For example, estrogen effects on certain aspects of hepatic lipid metabolism which are important in adipose tissue LPL activity may be reduced in immature rats (see Discussion, Chapter IV).

In male rats, EB treatment is unable to induce adipose progestin receptors, and progesterone treatment has no effect on adipose LPL activity (Gray and Wade, 1980; Siege1, 1981). These data suggest that cytoplasmic progestin receptors are necessary in order for progesterone treatment to have an effect on LPL activity. The present data indicate that while progestin receptors may be necessary, they are not sufficient for progesterone-induced changes in adipose tissue LPL activity. 


\section{H A P T E R V I}

\section{GENERAL DISCUSSION}

The present thesis was undertaken with two goals in mind. The f1rst was to confirm and extent findings on effects of ovarian steroids on food Intake, body weight and adiposity in prepubertal female rats. The second goal was to determine whether mechanisms which govern hormone-induced changes in adults could also account for the effects observed in young female rats. Rather than focusing on neural regulation, peripheral metabolic control mechanisms were investigated.

The results demonstrate that prior to puberty, estradiol decreases body weight, but it has no selective effect on adiposity or feeding behavior as it does in adults. One factor contributing to the attenuated responsiveness of $\mathrm{EB}$ may be that prepubertal rats have a lower concentration of adipose tissue cytoplasmic estrogen receptors as compared with adult animals. In contrast, the progestin receptor concentration in adipose tissue is comparable to adult levels. This latter finding helps explain progesterone's ability to affect body weight, adiposity and food intake in weanling females. These progesterone-induced changes, however, are not mediated by adipose tissue LPL activity, since neither estradiol nor progesterone treatment has any effect on the activity of this enzyme in immature rats.

Although most of the specific findings already have been discussed, there are two general aspects which warrent further attention. 
The Effect of Estradiol on Body Weight in Weanling Rats

Much emphasis has been placed on the fact that estrogen treatment had no effect on food intake or adiposity in prepubertal females. Nonetheless, it did significantly alter body weight gain. It would appear that this weight change represents a decrease in overall growth -- by 42 days of age, estrogen-treated animals were smaller in both somatic and skeletal development.

One factor which may be involved in this estrogen-induced stunting is pituitary $\mathrm{GH}$ whose growth-promoting actions are most obvious between birth and puberty (Martin, 1976). Previously, it was suggested that the reduced estrogen effect on food intake and adiposity observed in prepubertal females might involve antagonism by GH (Discussion, Chapter II). The EB-induced stunting, on the other hand, may involve antagonism by estrogen. In other words, estrogens, by antagonizing $\mathrm{GH}$, may decrease the rate of growth, resulting in a smaller (tissue mass) and shorter (skeletal mass) animal.

At 22 days of age, plasma GH levels begin increasing and peak around puberty (Eden, 1978). Administration of estrogen during this time might interfere with peripheral actions of $\mathrm{GH}$ on somatic growth (Herbai, 1971; Josimevich, Mintz and Finster, 1967; Schwartz, Weidmann, Simon and Schiffer, 1969) and/or directly decrease pituitary GH concentration (Dickerman, Dickerman and Meites, 1972; Haug and Gautvik, 1978; Jones, Fischer, Lewis and Vanderlaan, 1965).

Interference with $\mathrm{GH}$ action also might account for the inhibitory effects of estrogen on skeletal growth, especially in young animals 
(Gardner and Pfeiffer, 1943). Effects of $\mathrm{GH}$ on bone and cartilage are mediated primarily through the action of somatomedins, growthpromoting peptides (Daughaday, 1979; Martin, 1976). Thus, estrogens might alter skeletal growth by inhibiting somatomedin synthesis. It is of interest here to note that hypersecretion of estrogen in children also leads to a shortening of stature (Martin, 1976).

\section{The Paradox of Progesterone Treatment in Weanling Rats}

The other issue that I wish to address involves the ability of progesterone to alter adiposity and food intake in prepubertal animals. In adult females, a primary function of progesterone is to antagonize or attenuate the actions of estradiol on eating and body weight gain (Wade, 1976). Yet, in prepubertal females, these estrogen-induced changes are absent. Since the effectiveness of a hormone is strongly correlated with the concentration of target tissue receptors for that hormone (Leavitt et al., 1977; Wade and Gray, 1978; Gray, 1980), I suggested that one factor contributing to the paradoxical findings might be that while adipose progestin receptors show adult-like levels, estrogen binding sites are significantly lower than adults.

During the prepubertal period, estradiol-induced effects on food intake, adiposity, locomotor activity (Kennedy, 1964; Porterfield and Stern, 1974) and pituitary gonadotropin output (Dudley, 1980) are either absent or attenuated. Immature receptor binding systems, alphafetoprotein and/or antagonism by growth hormone are among the factors that have been postulated to account for the refractoriness. Nonethe- 
less, not all of estrogen's effects are absent at this time. Of concern here is estrogen's ability to stimulate the synthesis of adipose tissue progestin receptors (Chapter V). These results suggest that the presence of adult-like levels of progestin receptors is sufficient to induce certain progesterone actions such as changes in adiposity and food intake. On the other hand, progesterone's effect on adipose tissue LPL activity seems to require additional estrogenic actions. Thus, the progesterone-induced changes observed prepubertally must occur via mechanisms other than changes in LPL activity.

One way in which progesterone might exert its effects is through direct action on central regulation of feeding (e.g., Jankowiak and Stern, 1974). Progestins also might affect other peripheral metabolic processes involved in feeding and adiposity other than adipose tissue LPL activity. Progesterone directly influences several aspects of carbohydrate metabolism (Wade and Gray, 1979 for review), including increased insulin production in pancreatic islets (Howell, Tyhurst and Green, 1977). While in adult animals it is unlikely that ovarian hormones mediate adiposity and food intake via changes in carbohydrate metabolism (Wade and Gray, 1979), it is important to keep in mind that peripheral metabolism and tissue growth change as a function of age (Eden, 1978; Gray, 1980; Hartman and Christ, 1978; Hietanan and Greenwood, 1977; Holm, Jacobsson, Bjorntorp and Smith, 1975). This implies that regulatory mechanisms operating in adults may be both quantitatively and qualitatively different from those acting in young 
animals. In adipose tissue, age has been shown to influence basal lipolytic activity (Gruen et al., 1980), lipogenesis (Tsujikawa and Kimura, 1980), the activity of individual enzymes involved in lipolysis (Cooper and Gregerman, 1976) as well as lipolytic responses to hormones (Hartman and Christ, 1978; Holm et al., 1975). Thus, progestin effects may be governed by changes in adipose tissue metabolism but not necessarily through adult mechansism; for example, ovarian steroids appear to have no effect on lipolysis in adult animals (Steingrimsdottir et a1., 1980; Valette, Vernel and Varski, 1978). However, in prepubertal animals, progesterone-induced changes on body weight regulation and food intake might be mediated through changes in 1ipolytic activity (e.g., Sutter-Dub, Hamdan and Vergnaud, 1981) rather than fat deposition (i.e., IPL activity). Until the effects of ovarian hormones on lipolysis are thoroughly investigated in immature animals, this possibility cannot be ruled out.

It would be simplistic to assume that ovarian steroids regulate body weight and food intake by only one mechanism. Mechanisms governing steroid-induced changes may vary depending on the nutritional status of the animal (Mueller and Hsiao, 1980; Nance, 1980; Rednick et al., 1973) or the environment under which the animal is maintained such as the particular lighting condition (Schwatrz, unpublished results). The findings presented in this dissertation illustrate age also influences the mechanism by which ovarian steroids affect body weight regulation and feeding. 


\section{REFERENCES}

Anderson, J., E. Peck and J. Clark. Estrogen-induced uterine responses and growth: Relationship to receptor estrogen binding by uterine nuclei. Endocrinology, 96, 160-167, 1975.

Aten, R., M.J. Weinberger, and A.J. Eisenfeld. Estrogen receptor in rat liver: Translocation to the nucleus in vivo. Endocrinology, $102,433-442,1978$.

Beatty, W., D.A. O'Brient, and J.R. Vilberg. Effects of ovariectomy and estradiol injections on food intake and body weight in rats with ventromedial hypothalamic lesions. Pharmacol. Biochem. Behav., 3, 539-544, 1975 .

Ber, A. Body and organ weights in rats ovariectomized before puberty. Endokrinologie, 59, 187-196, 1972.

Bernardis, L. and B.D. Patterson. Correlation between 'Lee Index' and carcass fat content in weanling and adult female rats with hypothalamic lesions. J. of Endocr., 40, 527-528, 1968.

Blaustein, J. and G. Wade. Progestin binding by brain and pituitary cell nuclei and female sexual behavior. Brain Res., 140, 360367,1978 .

Bjorntorp, P., G. Enzi, R. Ohlson, B. Persson, P. Sporibergs and U. Smith. Lipoprotein lipase activity and uptake of exogenous triglycerides in $f$ at cells of different size. Horm. Metab. Res., 7. 230-237, 1975 . 
Brobeck, J.R., M. Wheatland and J.L. Strominger. Variations in regulation of energy exchange associated with estrus, diestrus, and pseudopregnancy in rats. Endocrinology, 40, 65-72, 1947.

Clark, J., J. Anderson and E. Peck. Nuclear receptor-estrogen complexes of rat uteri. In: Receptors for Reproductive Hormones, edited by B. O'Ma11ey and A. Means, N.Y.: Plenum Press, 1973, pp. $15-59$.

Clark, R. and M. Tarttelin. The linear regression of body weight and age in intact, ovariectomized, and estrogen treated rats: Some applications and implications. Growth, 42, 113-127, 1978.

Colvin, G.B. and S.H. Sawyer. Induction of running activity by intracerebral implants of estrogens in ovariectomized rats. Neuroendocrinology, 4, 309-320, 1969.

Cooper, B. and R. Gregerman. Hormone-sensitive fat-cell adenylate cyclase in the rat. Influences of growth, cell size and aging. J. C1in: Invest., 57, 161-168, 1976 .

Daughaday, W. Anterior pituitary. In: Contemporary Endocrinology, edited by S. Ingbar, New York: Plenum Medical Book, 1979, pp. 2175 .

De Hertoch, R., E. Ekka, I. Vanderheyden and J. Hoct. Metabolic clearance rates and the interconversion factors of estrone and estradiol $17 \beta$ in the immature and adult female rat. Endocrinology, 87, $874-880,1970$

Dickerman, E., S. Dickerman and J. Meites. Influence of age, sex and estrous cycle on pituitary and plasma growth hormone levels in 
rats. In: Growth and Growth Hormone, edited by A. Pecile and E. Muller, Amsterdam: Excerpta Medica, 1972.

Dubuc, P. Prepubertal estrogen treatment and somatic growth in rats. Endocrinology, 98, 623-628, 1976.

Dudley, S. Prepubertal ontogeny of estradiol responsiveness in the

female rat. Neurosci. Biobehav. Rev., in press, 1981.

Edens, S. The secretory pattern of growth hormone. Acta Physio.

Scand. Supp., 458, 1-54, 1978.

Eden, S., K. Albertsson-Wilkland and 0 . Isaksson. Plasma levels of growth hormone in female rats of different ages. Acta Endocri. $676-690,1978$

Eisenfeld, A.J. [ $\left.{ }^{3} \mathrm{H}\right]$ estradiol: In vitro binding to macromolecules from rat hypothalamus, anterior pituitary and uterus. Endocrinology, 86, 1313-1326, 1970 .

Eisenfeld, A.J. and R.A. Aten. Estrogen receptor in the mammalian liver. In: Advances in Steroid Biochemistry and Pharmacology, vol. 7, edited by M.H. Briggs and A. Corbin, New York: Academic Press, 1979, pp. 91-117.

Eisenfeld, A.J., R.F. Aten, and R.B. Dickson. Estrogen receptor in the mammalian liver. In: Estrogens in the Environment, edited by J. McLachlan, Amsterdam: Elsevier, 1980, pp. 69-96.

Eisenfeld, A.J., R. Aten, M. Weinberger, G. Haselbacher and K. Halbern. Estrogen receptor in the mammalian 1iver. Science, 191, 862866,1976 
Eisenfeld, A.J. and Axelrod. Selectivity of estrogen distribution in

tissues. I. Pharmac. exp. Ther., 150, 469-475, 1965.

Fain, J.N. Studies on the role of RNA and protein synthesis on the lipolytic activity of $\mathrm{GH}$ in isolated fat cells. Adv. Enzyme Regu1., $\underline{5}, 39-45,1967$.

Fain, J.N., V.P. Kovacev and R.O. Scow. Effect of growth hormone and dexamethas one on lypolysis and metabolism in isolated fat cells of the rat. J. Bio1. Chem., 240, 3522-3526, 1965.

Fergus on, E.R. and B.S. Katzenellenbogen. A comparative study of antiestrogen action: temporal patterns of antagonism of estrogen stimulated uterine growth and the effects on estrogen receptor levels. Endocrinology, 100, 1242-1251, 1977.

Friedman, M. and E.M. Stricker. The physiological psychology of hunger: A physiological perspective. Psychol Rev., 83, 409$431,1976$.

Galletti, F. and A. Klopper. The effect of progesterone on the quantity and distribution of body fat in the female rat. Acta Endocri., 6, 379-386, 1967 .

Gardner, W. and C. Pfeiffer. Influence of estrogens and androgens on the skeletal system. Physiol. Rev., 23, 139-165, 1943.

Germain, B., P. Campbell and J. Anderson. Role of the serum estrogenbinding protein in the control of tissue estradiol levels during postnatal develpoment of the female rat. Endocrinology, 103, $1401-1410,1978$. 
Ginsburg, M., B.D. Greenstein, N.J. MacLusky, I.D. Morris, and P.J.

Thomas. An improved method for studying high affinity steroid binding: Oestradiol binding in brain and pituitary. Steriods, $\underline{23}, 772-791,1974$.

Goodman, H.M. Separation of early and late responses of adipose tissue to growth hormone. Endocrinology, 109, 120-129, 1981.

Gorski, J. Models of estrogenic-hormone action. In: Estrogens in the Environment, edited by J. McLachlan, Amsterdam, Elsevier, 1980, pp. 3-10.

Gorski, J. and F. Gannon. Current models of steroid hormone action:

A critique. Ann. Rev. Physiol., 38, 425-450, 1976.

Gray, J.M. Cytoplasmic progestin binding in adipose tissues, and the effect of progestins on food intake, adiposity, and lipoprotein lipase activity. Doctoral Dissertation, 1980.

Gray, J. The development of lipid metabolism patterns in the rat, unpublished paper.

Gray, J.M., S. Dudley and G.N. Wade. In vivo nuclear uptake of $\left[{ }^{3} \mathrm{H}\right]-$ estradiol in adipose tissues. Am. J. Physiol., 240, E43-E46, 1981

Gray, J.M. and G.N. Wade. Cytoplasmic progestin binding in rat adipose tissues. Endocrinology, 104, 1377-1382, 1979.

Gray, J.M. and G.N. Wade. Cytoplasmic estrogen, but not progestin, binding sites in adipose tissues in male rats. Am. I. Physiol., 239, E237-E241, 1980. 
Gray, J.M. and G.N. Wade. Food intake, body weight, and adiposity in female rats: Actions and interactions of progestin and antiestrogens. 쇼. J. Physio1., 240, E474-E481, 1981.

Gruen, R., R. Kava and M.R.C. Greenwood. Development of basal lipolysis and fat cell size in the eipdidymal fat pad of normal rats. Metabolism, 29, 246-253, 1980.

Grunt, J.A. Effects of neonatal gonadectomy on skeletal growth and development in the rat. Endocrinology, 75, 805-808, 1964.

Hamosh, M. and P. Hamosh. The effect of estrogen on the lipoprotein lipase activity of rat adipose tissue. J. $\underline{\mathrm{C} l i n}$. Invest., $\underline{55}$, $1132-1135,1975$.

Hartman, A. and D. Christ. Effect of cell size, age and anatomical location on the lipolytic response of adipocytes. Life. Sci., 22, $1987-1096,1978$.

Haug, E. and K.M. Gautvik. Effects of sex steroids on growth hormone production in cultured rat pituitary cells. Acta Endocrinol., 87, 40-54, 1978.

Heggeness, F.W. Effect of intermittent food restriction on growth, food utilization and body composition of the rat. J. Nutr., 86 , $265-270,1965$.

Herbai, G. Studies on the site and mechanism of action of the growth inhibiting effects of estrogens. Acta Physiol. Scand., 83, 7790,1971

Hervey, E. and G.R. Hervey. The relationship between the effects of ovariectomy and of progesterone treatment on body weight and 
composition in the female rat. J. Physiol. (Lond), 87, 44P45P, 1966.

Hervey, E. and G.R. Hervey. The effects of progesterone on body weight and composition in the rat. J. Endocrinol., 37, 361384,1967 .

Hervey, E. and G.R. Hervey. Energy storage in female rats treated with progesterone in the absence of increased food intake. J. Physiol., 200, 118P-119P, 1968.

Hervey, E. and G.R. Hervey. The effects of progesterone on the quantity and distribution of body fat in the female rat. Acta Endocri., 46, 379-386, 1976.

Hietanan, E. and M.R.C. Greenwood. A comparison of lipoprotein lipase activity and adpocyte differentiation in growing male rats. J. Lipid Res., 18, 480-490, 1977.

Holm, G., B. Jacobson, P. Bjorntorp and 0. Smith. Effects of age and cell size on rat adipose tissue matabolism. J. Lipid Res., 16, 461-464, 1975.

Howell, S., M. Tyhurst, and I. Green. Direct effects of progesterone on rat islets of langerhans in vivo and in tissue culture. Diabetologia $, 13,579-583,1977$.

Janowiak, R. and J. Stern. Food intake and body weight modifications following medial hypothalamic hormone implants in female rats. Physiol. Behav., 12, 875-879, 1974.

Jones, A., J. Fisher, U. Lewis and W. VanderLaan. Electrophoretic comparison of pituitary glands from male and female rats. 
Endocrinology, 76, 578-582, 1965.

Josimevich, J., D.H. Mintz and J.L. Finster. Estrogenic inhibition

of growth hormone-induced tibial epiphyseal growth in hypophysectomized rats. Endocrinology, 81, 1428-1434, 1967.

Katzenellenbogen, B. Regulation of uterine responsiveness to es-

trogen: Developmental and multihormonal factors. In:

Ontogeny of Receptors and Reproductive Hormone Action, edited by T. Hamilton, J. Clark and W. Sadler, N.Y.: Raven Press, 1979, pp. 79-102.

Kennedy, G.C. The role of depot fat in the hypothalamic control of

food intake in the rat. Proc. Roy. Soc. Ser. B., 140, 578$592,1953$.

Kennedy, G.C. Ontogeny of mechanisms controlling food intake and water intake. In: Handbook of Physiology, Sec. $\underline{6}$ : Alimentary Canal, Vol.1: Control of Food and Water Intake, edited by C.F. Code. Washington, D.C.: Amer. Physio1. Soc., 1967, pp. 337351.

Kennedy, G.C. Interactions between feeding behavior and hormones during growth. Ann. N.Y. . Acad. Sci., 157, 1049-1061, 1969. Kim, H.J. and Kalkhoff. Altered apolipoproteins in sex steroidtreated rats. Metabolism, 27, 571-587, 1978.

King, J.M. and V.C. Cox. The effects of estrogens on food intake and body weight following ventromedial hypothalamic lesions. Physiol. Psycho1., 1, 261-264, 1973. 
Kronibus, J. and W. Wuttke. Positive feedback action of oestradiol on gonadotropin release in 15 day old female rats. Acta Endocri., 86, 263-272, 1977.

Krotkiewsk1, M. and P. Bjorntorp. The effect of progesterone and of insulin administration in regional adipose tissue cellularity in the rat. Acta Physiol. Scand., 96, 122-127, 1976.

Kurtz, D., A.E. Sippel, R. Ansah-Yiadom and P. Feigelson. Effects of sex hormones on the level of mRNA for the rat hepatic protein 2 globulin. J. Biol. Chem., 251, 3594-3598, 1976.

Lowry, O., N.J. Rosebrough, A.C. Farr and R.J. Randall. Protein measurement with the Folin phenol reagent. J. Biol. Chem., 193, 265-275, 1951 .

Leshner, A. and G.C. Collier. The effects of gonadectomy on the sex differences in dietary self-selection patterns and carcass composition of rats. Physiol. Behav., 11, 671-676, 1973.

Leshner, A., V.A. Litwin and R.I. Squibb. A simple method for carcass analysis. Physiol. Behav., 9, 281-282, 1972.

Martin, C. Textbook of Endocrine Physiology. New York: Oxford Press, 1976.

MacLusky, N.J., C. Chaptal and B. MeEwen. The development of estrogen receptor systems in the rat brain and pituitary: Postnatal development. Brain Research, 178, 143-160, 1979.

Maclusky, N.J., C. Chaptal, I. Lieberburg and B.S. McEwen. Properties and subcellular interrelationships of presumptive estrogen receptor macromolecules in the brains of neonatal and prepubertal 
female rats. Brain Res., 114, 158-164, 1976.

MacLusky, N.J. and B.S. McEwen. Oestrogen modulates progestin receptor concentrations in some brain regions but not others. Nature, $274,276-278,1978$.

McEwen, B.S. Sexual maturation and differentiation: The role of the gonadal steroids. In: Maturation of the Nervous System, Progress in Brain Research, edited by M.A. Corner, Amsterdam: Elsevier, 1978.

McEwen, B.S., L. Plapinger, C. Chaptal, J. Gerlach, and G. Wallach. Role of fetonatal estrogen binding proteins in the association of estrogen with neonatal brain cell receptors. Brain Res., $\underline{6}$, 400-406, 1975 .

Meijs-Roelofs, H., J. Vilenbroek, F. De Jong and R. Welschen. Plasma estradio1-17及 and its relationship to serum follicle-stimulating hormone in immature female rats. J. Endocr., 59, 295-310, 1973. Mook, D.G., N.J. Kenney, S. Roberts, A. Nussbaum and W. Rodier. Ovarian-adrenal interactions in regulation of body weight by female rats. J. Comp. Physiol. Psychol., 81, 198-211, 1972.

Mueller, K. and S. Hsaio. Estrous- and ovariectomy-induced body weight changes: Evidence for two estrogenic mechanisms. J. Comp. Physio1. Psychol., 94, 1126-1134, 1980.

Mueller, K. and S. Hsaio. Effectiveness of estradiol in preventing and reversing obesity induced by ovariectomy and high caloric diet in female rats. J. Comp. Physio1. Psychol., 95, 61-70, 1981. 
Nance, D. Neuroestrogenic control of feeding behavior in the rat: Its development and regulation. In: Advances in Modern Human Nutrition, Vol. $\underline{2}$, edited by R.B. Tobin and M. Mehlman, Park Forest South, IL: Pathotox, 1980.

Nunez, A., J.M. Gray, and G.N. Wade. Food intake and adipose tissue lipoprotein lipase activity after hypothalamic estradiol benzoate implants in rats. Physiol. Behav., 25, 595-598, 1980. Ojeda, S.R. and H.E. Jameson. Developmental patterns of plasma and pituitary growth hormone (GH) in the female rats. Endocrinology, 100, 881-889, 1977.

Ojeda, S.R., P.S. Kalra, and S.M. McCann. Further studies on the maturation of the estrogen negative feedback on gonadotropin release in the female rat. Neuroendocrinology, 18, 242-255, 1975 .

O'Malley, B.W. and A.R. Means. Female steroid hormones and target ce11 nuclei. Science, 183, 610-620, 1974.

Patsch, W., K. Kim, W. Wiest and G. Schonfield. Effects of sex hormones on rat 1ipoproteins. Endocrinology, 107, 1085-1094, 1980 .

Porterfield, A.L. and J. Stern. Growth hormone and the refractoriness of the prepubertal activity system to estradiol in the rat. Physiol. Psycho1., 2, 23-25, 1974.

Ramaley, J. Development of gonadotropin regulation in the prepubertal mamma1. Biol. Repro., 20, 1-31, 1979. 
Ramirez, I. Relation between estrogen-induced hyperlipemia and food intake and body weight in rats. Physiol. Behav., 25, 511-518, 1980.

Ramirez, V. and C. Sawyer. Advancement of puberty in the female rat by estrogen. Endocrinology, 76, 1158-1168, 1965.

Raynaud, J.P. Influence of rat estradiol binding plasma protein (EBP) on uterotrophic activity. Steroids, 21, 249-258, 1973.

Raynaud, J.P. R5020, a tag for the progestin receptor. In:

Progesterone Receptors in Normal and Neoplastic Tissues, edited by W. McGuire, W. Raynaud and J.P. Baulieu, New York: Raven Press, 1977, pp. 9-21.

Raynaud, J.P., C. Mercier-Bodard and E. Baulieu. Rat estradiol binding plasma protein (EBP). Steroids, 18, 767-788, 1971. Rednick, J., A.I. Nussbaum and D.G. Mook. Estradiol-induced suppression of feeding in the female rat: Dependence on body weight. Physiol. Behav., 10, 543-547, 1973.

Roberts, S., N.J. Kenney and M.G. Mook. Overeating induced by progesterone in the ovariectomized, adrenalectomized rat. Horm. Behav., 3, 267-276, 1972 .

Robinson, D.S. The function of plasma triglycerides in fatty acid transport. In: Comprehensive Biochemistry, 18, edited by $M$. Florkin and E. Stotz, Amsterdam: Elsevier, 1970, pp. 51-115. Ross, G.E. and I. Zucker. Progesterone and the ovarian-adrenal modulation of energy balance in rats. Horm. Behav., 5, 43-62, 1974. 
Rothchild, I. The neurologic basis for the anovulation of the luteal phase, 1actation, and pregnancy. In: Reproduction in the

Mamma1, edited by G.E. Lamming and E.C. Himoroso, New York: Plenum Press, 1967, pp. 30-54.

Roy, A., D.M. McMinn and N.M. Biswas. Estrogen inhibition of the hepatic synthesis of 2 globulin in the rat. Endocrinology, 97, $1501-1508,1975$

Roy, E. and G.N. Wade. Role of food intake in estradiol-induced body weight changes in female rats. Hormones Behav., 8, 265-274, 1977.

Salans, L.B. Influence of progestin and estrogen on fat cell size, number, glucose metabolism and insulin sensitivity. Fiftythird Annual Meeting of the Endocrine Society, San Francisco, 1971, abstract no. 33 .

Schwartz, E., E. Wiedemann, S. Simon and M. Schiffer. Estrogenic antagonism of administered growth hormone. J. $\underline{\mathrm{C} l i n}$. Endocrinol. Metab., 29, 1176-1181, 1969.

Schotz, M., A. Garfinkel, R.J. Huebotter and J.E. Stewart. A rapid assay for lipoprotein lipase. J. Lipid Res., 11, 68-69, 1970. Sieck, G.C., D. Nance, adn R. Gorski. Estrogen modification of feeding behavior in the female rat: Influence of metabolic state. Physiol. Behav., 21, 893-897, 1978.

Sieck, G.C., D. Nance, J.A. Ramaley, A.N. Taylor and R.A. Gorski. Prepubertal cyclicity in feeding behavior and body weight regulation in the female rat. Physiol. Behav., 18, 299-305, 1977. 
Siege1, L. Androgen effects on food intake, body weight, and carcass composition in male rats. Doctoral Dissertation, 1981.

Smith, B.D. The effect of diethystilbestrol on the immature rat ovary. Endocrinology, 69, 238-243, 1961.

Smith, E. and J. Davidson. Role of estrogen in the cerebral control of puberty in female rats. Endocrinology, 82, 100-107, 1968.

Slob, A. Perinatal endocrine and nutritional factors controlling physical and behavioral development in the rat. Doctoral Dissertation, 1972 .

Steingrimsdottir, L., J. Brasel and M.R.C. Greenwood. Hormonal modulation of lipoprotein lipase may alter food intake in rats. Am. I. Physio1., 239, E162-E167, 1980.

Stephens, D. Does the Lee Obesity index measure general obesity? Physiol. Behav., 25, 313-315, 1980.

Sutter-Dub, M., B. Dazey, E. Hamdan and M. Vergriaud. Progesterone and insulin-resistence: Studies of progesterone action on glucose transport, lipogenes is and lipolysis in isolated fat cells of the female rat. J. Endocr., 88, 455-462, 1981.

Tartellin, M. and R. Gorski. The effects of ovarian steroids on food and water intake and body weight in the female rat. Acta Endocr. , 72, 551-558, 1973.

ter Haar, M.B. Circadian and estrial rhythms in food intake in the rat. Horm. Behav., $\underline{3}, 213-219,1972$.

Tsujikawa, M. and S. Kimura. Changes in lipid synthesis in rat adipose tissue during development. I. Nutr. Sci. Vitaminol., 26, 367- 
374,1980 .

Valette, A., A. Vernel and C. Varski. Effects of ethyl estradiol and progesterone on triglyceride metabolism in the female rat. Endocrinology, 103, 1647-1653, 1978.

Wade, G.N. Interaction between estradiol-17 $\beta$ and growth hormone in control of food intake in weanling rats. J. Comp. Physiol. Psycho1., 86, 354-362, 1974.

Wade, G.N. Effects of ovarian hormones on food intake and body weight in female rats. J. Comp. Physiol. Psychol., 88, 183-193, 1975. Wade, G.N. Sex hormones, regulatory behaviors, and body weight. In: Advances in the Study of Behavior (Vol. 6), edited by J. Rosenblatt, R.A. Hinde, E. Shaw and C.G. Beer, New York: Academic Press, 1976.

Wade, G.N. and J.M. Gray. Cytoplasmic $17 \beta-\left[{ }^{3} \mathrm{H}\right]$ estradiol binding in rat adipose tissues. Endocrinology, 103, 1695-1701, 1978. Wade, G.N. and J.M. Gray. Gonadal effects on food intake and adiposity: A metabolic hypothesis. Physiol. Behav., 22, 583-593, 1979. Wade, G.N. and I. Zucker. Modulation of food intake and locomotor activity in female rats by diencephalic hormone implants. J. Comp. Physiol. Psychol., 70, 328-338, 1970a.

Wade, G.N. and I. Zucker. Development of hormonal control over food intake and body weight in female rats. J. Comp. Physiol. Psychol., 70, 213-220, 1970b.

Wang, G.H. The relation between 'spontaneous' activity and oestrous cycle in the white rat. Comp. Psychol. Monogr., ii, No. 6, 1923. 
Watkins, M.L., N. Fizette and M. Heinberg. Sexual influences in

hepatic secretion of triglyceride. Biochem. Biophys. Acta, 280, $82-85,1972$.

Weisz, J. and P. Gunsalus. Estrogen levels in immature female rats:

True or spurious-ovarian or adrenal? Endocrinology, 93, 10571065, 1972 .

White, J., C. Hall and L. Lim. Developmental changes in the content of oestrogen receptors in the hypothalamus of the female rat. Biochem. J., 184, 465-468, 1979.

Widdows on, E. and F.R.S. McCance. Some effects of accelerating growth

I. General somatic development. Proc. R. Soc. B., 152, 188206, 1960 .

Yamamoto, K. and B.M. Alberts. Steroid receptor elements for modulation of eukaryotic transcription. Ann. Rev. Biochem., 197, 722-746, 1976.

Zucker, I. Hormonal determinants of sex differences in saccharin preference, food intake and body weight. Physiol. Behav., 4 , 595-602, 1969

Zucker, I. Body weight and age as factors determining estrogen responsiveness in the rat feeding system. Behav. Biol., ㄱ, 527542,1972 . 
10 .

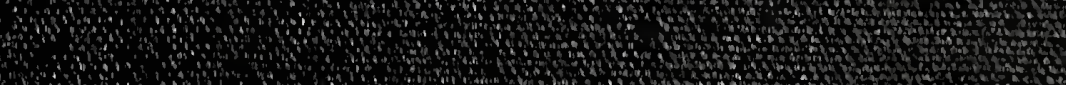
(1) a

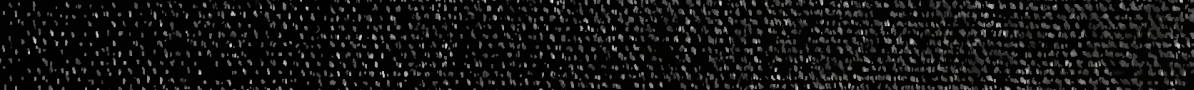
( 烈 然

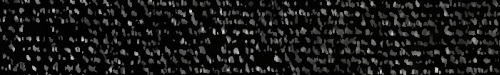
(1) and (n) (1) (n) (n) (1) (1)

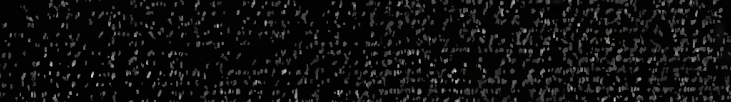

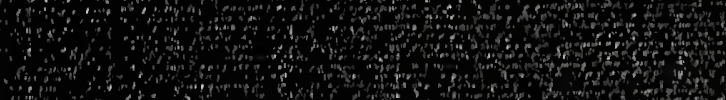
and

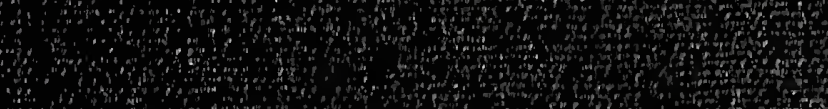

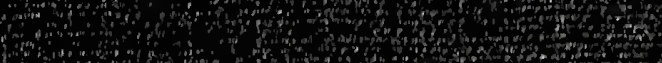

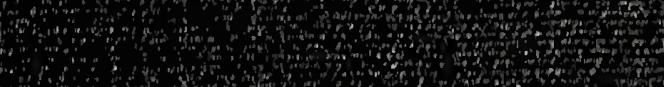
(n) (n) (n) (

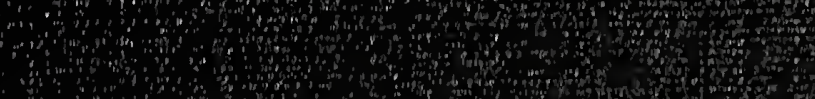
(n) 